\title{
Impacts of Land-Use/Land-Cover Change on Afternoon Precipitation over North America ${ }^{\circ}$
}

\author{
Liang Chen AND PAUl A. DiRMeyer \\ Center for Ocean-Land-Atmosphere Studies, George Mason University, Fairfax, Virginia
}

(Manuscript received 11 August 2016, in final form 21 November 2016)

\begin{abstract}
This study investigates the impacts of historical land-cover change on summer afternoon precipitation over North America using the Community Earth System Model. Using land-atmosphere coupling metrics, this study examines the sensitivity of afternoon atmospheric conditions to morning land surface states and fluxes that are altered by land-cover changes before and since 1850 . The deforestation in the eastern United States prior to 1850 leads to increased latent but decreased sensible heat flux during the morning and a reduction in afternoon precipitation over the southern regions of the U.S. East Coast. The agricultural expansion over the Great Plains since preindustrial times shows similar effects on surface fluxes but results in a significant widespread increase in precipitation over the crop area. The coupling metrics exhibit a strong positive soil moisture-precipitation relationship over the Great Plains. Impacts of land-cover change on precipitation manifest through changes in rainfall frequency, rather than intensity, that are largely controlled by the distribution of CAPE as the trigger of convective precipitation. However, deforestation and later reforestation over the eastern United States, where coupling properties are different than the Great Plains, do not have as dominant an effect on afternoon precipitation. Additionally, precipitation over parts of the U.S. Southwest decreases in this model during the earlier period of East Coast deforestation, owing to changes in the large-scale circulation over North America driven by land-use changes prior to 1850 .
\end{abstract}

\section{Introduction}

During the period $1700-2000$, between $42 \%$ and $68 \%$ of the global land surface was altered through human activities such as cropland and pasture expansion and wood harvest (Hurtt et al. 2006). These land-use/ land-cover changes can affect the energy and water exchange between the land surface and atmosphere, thereby impacting the climate at regional and global scales (Feddema et al. 2005; Lawrence and Chase 2010). Previous studies have demonstrated the impacts of historical land-use/land-cover change on temperature and precipitation (e.g., Findell et al. 2007; Mahmood et al. 2014; Pitman et al. 2009; Xu et al. 2015). Among these studies, the impacts of land-cover change on temperature at different temporal scales (e.g., seasonal and diurnal) have been well documented. However, large uncertainties remain in our understanding of the

Supplemental information related to this paper is available at the Journals Online website: http://dx.doi.org/10.1175/JCLI-D-16-0589.s1.

Corresponding author e-mail: Liang Chen, lchen15@gmu.edu impacts on precipitation because of the more-complex processes involved (Pielke et al. 2007).

There have been many studies focusing on the local impacts of soil moisture on precipitation using both observations (e.g., Alfieri et al. 2008; Ford et al. 2015a) and climate models (e.g., Dirmeyer 2006; Koster et al. 2009; Seneviratne et al. 2010). Within the water cycle, soil moisture and evapotranspiration (ET) influence each other. Surface ET further affects precipitation, which in turn feeds back to soil moisture (Seneviratne et al. 2010). Generally, there are two somewhat opposite mechanisms involved in the soil moisture-precipitation coupling. First, wet soil may enhance ET and thereby moisten the boundary layer, typically leading to increased convective available potential energy (CAPE) and improved likelihood of convective initiation. These processes lead to a positive soil moisture-precipitation coupling through an increase of low-level moist static energy (Anthes 1984; Pal and Eltahir 2001). Alternatively, Bowen ratios are usually high over dry soil, whose high sensible heat flux decreases relative humidity and increases air temperature near the surface. These changes act through the energy cycle to enhance PBL 
growth, which may enable penetration of the lifting condensation level (LCL), and initiation of moist convection and subsequent precipitation. This second mechanism is more favorable over arid regions where humidity is sparse and cloud bases are high (Findell and Eltahir 2003). Spatial variations in soil moisture can allow these two mechanisms to exist at different times in the same location (e.g., Roundy et al. 2013; Song et al. 2016) or to work in concert, setting up mesoscale circulations that create a regional soil moisture-precipitation coupling pathway (Guillod et al. 2015; Taylor et al. 2013).

Recently, some studies have focused on the influence of ET [or evaporative fraction (EF)] on precipitation, which is the most uncertain link within the soil moistureprecipitation coupling framework (Seneviratne et al. 2010). By applying the triggering feedback strength (TFS) and amplification feedback strength (AFS) metrics to NARR, Findell et al. (2011) found that the probability of afternoon rainfall is significantly sensitive to morning EF over the eastern United States and Mexico, but the intensity of rainfall is largely insensitive to the surface fluxes. This conclusion was further reinforced by Berg et al. (2013) using the Geophysical Fluid Dynamics Laboratory's atmospheric model. However, a detailed diagnosis of the EF-precipitation relationship using NARR and observations (Guillod et al. 2014) indicates disagreement between the reanalysis and observations and suggests that the strong EF-precipitation relationship in the eastern United States in NARR is either atmospherically controlled or driven by vegetation interception, while the strong relationship over the central and southwestern United States is additionally linked to soil moisture.

In spite of these research efforts, few studies have specifically investigated the role of land-use/land-cover change within the soil moisture-precipitation coupling framework. Trail et al. (2013) suggested that replacing forested land with cropland in the southeastern United States tends to cool the surface air but does not have significant impact on precipitation. Collow et al. (2014) found that a complete removal of current vegetation would substantially reduce convective precipitation over the U.S. Great Plains, while conversion to forest leads to modest differences. Additionally, irrigation in the Great Plains also has been demonstrated to have significant impact on summer precipitation (e.g., Harding and Snyder 2012; Qian et al. 2013). However, studies that investigate the impact of land-use/land-cover changes in the context of the processes involved in soil moistureprecipitation coupling have been lacking.

The aim of this study is to determine a way to quantify and attribute precipitation responses to land-cover change within an Earth system model. We seek a method to isolate the locally initiated precipitation from the perspective of local coupled land-atmosphere interactions (Santanello et al. 2011a) so that the influence of land-cover change on the large-scale circulation $(\mathrm{Fu}$ 2003) and teleconnections (e.g., Badger and Dirmeyer 2016) can be excluded. By focusing on the water cycle as a pathway, mechanisms of the impact of land-cover change on precipitation may be elucidated.

In this study, afternoon precipitation events during boreal summer are the focus because the sensitivity of convection to land conditions is expected to be the greatest during this season and time of day (Dirmeyer et al. 2003; Song et al. 2016; Taylor et al. 2012). Many studies have documented land-atmosphere interactions over North America, especially concentrating on how land surface conditions (such as soil moisture, surface heating, and evaporative fraction) influence the atmosphere (e.g., Alfieri et al. 2008; Dirmeyer et al. 2013; Findell et al. 2011; Tawfik et al. 2015). Also, the Great Plains, one of the "hot spots" of land-atmosphere interactions, are located in this region (Koster et al. 2004). Therefore, this study focuses on the land-atmosphere interactions over North America, even though a global climate model is used. We examine the impacts of land-use/land-cover change on afternoon precipitation over North America, especially how morning land surface conditions influence the atmosphere by afternoon, and further investigate land-atmosphere coupling strength in response to land surface changes.

Section 2 describes the model, experiment design, and metrics used to investigate the role of land-use change in altering afternoon precipitation. Analysis of results is presented in section 3. A discussion of implications in the context of previous studies is given in section 4 , and section 5 presents conclusions.

\section{Methodology}

\section{a. Model description}

We use the Community Earth System Model (CESM) in this study. CESM is a coupled Earth system model composed of separate climate system components for atmosphere, ocean, land, sea ice, and land ice (Vertenstein et al. 2013). Because our focus is on landatmosphere interactions from the physical climate perspective, only the Community Atmosphere Model (CAM4.0; Neale et al. 2010) and Community Land Model (CLM4.5; Oleson et al. 2013) components have been activated. Carbon-nitrogen cycling is not active in CLM in this study. In CAM, the deep convection scheme responsible for most convective precipitation 
is developed by Zhang and McFarlane (1995), in which deep convection is triggered when CAPE exceeds $70 \mathrm{~J} \mathrm{~kg}^{-1}$.

\section{b. Experimental design}

Three land-cover scenarios are used in the experiments, corresponding to the last millennium (AD 850), preindustrial (AD 1850), and present conditions (AD 2000). The reconstructed last-millennium land-cover condition is adopted from the Last Millennium Ensemble (LME) project (Otto-Bliesner et al. 2015), which merged the reconstructions of land use/land cover by Pongratz et al. (2008) and Hurtt et al. (2011). Details of the datasets for land cover in 1850 and the present can be found in Lawrence et al. (2012). Two separate land-cover change scenarios are used for two reasons: 1) a more realistic representation of long-term historical land-use/ land-cover change and 2) the opportunity for more robust and enlightening findings about land-atmosphere interactions in terms of land-cover changes, not only over North America, which is the focus of this study, but globally.

Figure 1 shows the changes in trees, grass, and crops from 850 to 1850 and further changes from 1850 to present over North America. There has been little change in shrubs, which is not shown. Generally, landuse/land-cover changes have been driven by agricultural expansion, during which there has mainly been an increase in cropland at the expense of forest and grassland. Between 850 and 1850, cropland expansion and deforestation occurred over the eastern United States corresponding to European colonization and national expansion. From 1850 to the present, reforestation via abandonment of land cleared for farming occurred over much of the northeastern United States, where there has also been increased grassland. Meanwhile, extensive agricultural activities expanded over the greater Mississippi River basin in North America, where large areas of grassland and forest were replaced with cropland.

A set of coupled simulations with different land-cover conditions have been conducted with CESM (Table 1). For the three coupled experiments, which are climatology simulations with cyclic circa-year-2000 forcing, there are identical prescribed sea surface temperature (SST) and sea ice cover climatologies with a fixed $\mathrm{CO}_{2}$ concentration of $367.0 \mathrm{ppm}$. The climatic differences among the three simulations can be considered to be solely the result of land-cover changes. The prescribed SSTs are a monthly mean climatology calculated from 1982 to 2001 (Hurrell et al. 2008), which is derived from a merged product based on the monthly mean Hadley Centre Sea Ice and SST dataset, version 1 (HadISST1), and version 2 of the NOAA weekly Optimum Interpolation SST (OISST2) analysis.
All simulations are run at a horizontal resolution of $0.9^{\circ} \times 1.25^{\circ}$ with hourly output. Because of data storage limits, only 45-yr simulations (with 5 years for spinup) are conducted. To ensure the robustness of climatological signals of land-cover-induced changes is not compromised by the short-term simulations, two additional ensemble simulations are carried out for each experiment; only monthly history files are produced. Round-off level (of order $10^{-14} \mathrm{~K}$ ) differences are applied to the air temperature field in atmospheric initial conditions to generate additional ensemble members. Most of the analysis is still conducted on the hourly output from the first ensemble, while the results from monthly output are also compared with the three-ensemble average as an additional evaluation on the robustness of the land surface and atmospheric response to land-cover changes. Most land-use/land-cover changes have occurred over the Northern Hemisphere, and land-atmosphere interactions are particularly strong during the warm season. Therefore, only boreal summer (JJA) is the focus of this study.

\section{c. Model evaluation}

Since this study is a model-dependent investigation, the performance of CESM in simulating afternoon precipitation is first evaluated against precipitation observations from the multisource weighted-ensemble precipitation (MSWEP) dataset. The MSWEP dataset provides 3-hourly precipitation estimations with $0.25^{\circ} \times$ $0.25^{\circ}$ spatial resolution from 1979 to 2015 over land, which merges the highest-quality precipitation sources available, including two gauge observations, three satellite products, and two reanalysis datasets (Beck et al. 2017). To be comparable with the climatological CESM simulation, the MSWEP dataset is regridded to $0.9^{\circ} \times$ $1.25^{\circ}$ with bilinear interpolation, and only precipitation observations from 1982 to 2001 are used, corresponding to the same period of monthly mean climatology of prescribed SST used in the CESM simulations. Figure S1 in the supplementary material shows the comparison in summer afternoon precipitation between MSWEP and the CESM simulation with 2000 land-cover conditions. Overall, the model shows a good performance over the Midwest and the Great Plains, but there is underestimated afternoon precipitation especially over the northeastern United States, the Gulf Coast, and the Rockies.

\section{d. Land-atmosphere coupling strength}

A two-legged coupling metric (Dirmeyer 2011; Guo et al. 2006; Wei and Dirmeyer 2012) is used to assess land-atmosphere interactions. The terrestrial leg connects soil moisture and surface fluxes, while the atmospheric leg is the linkage between surface fluxes and 

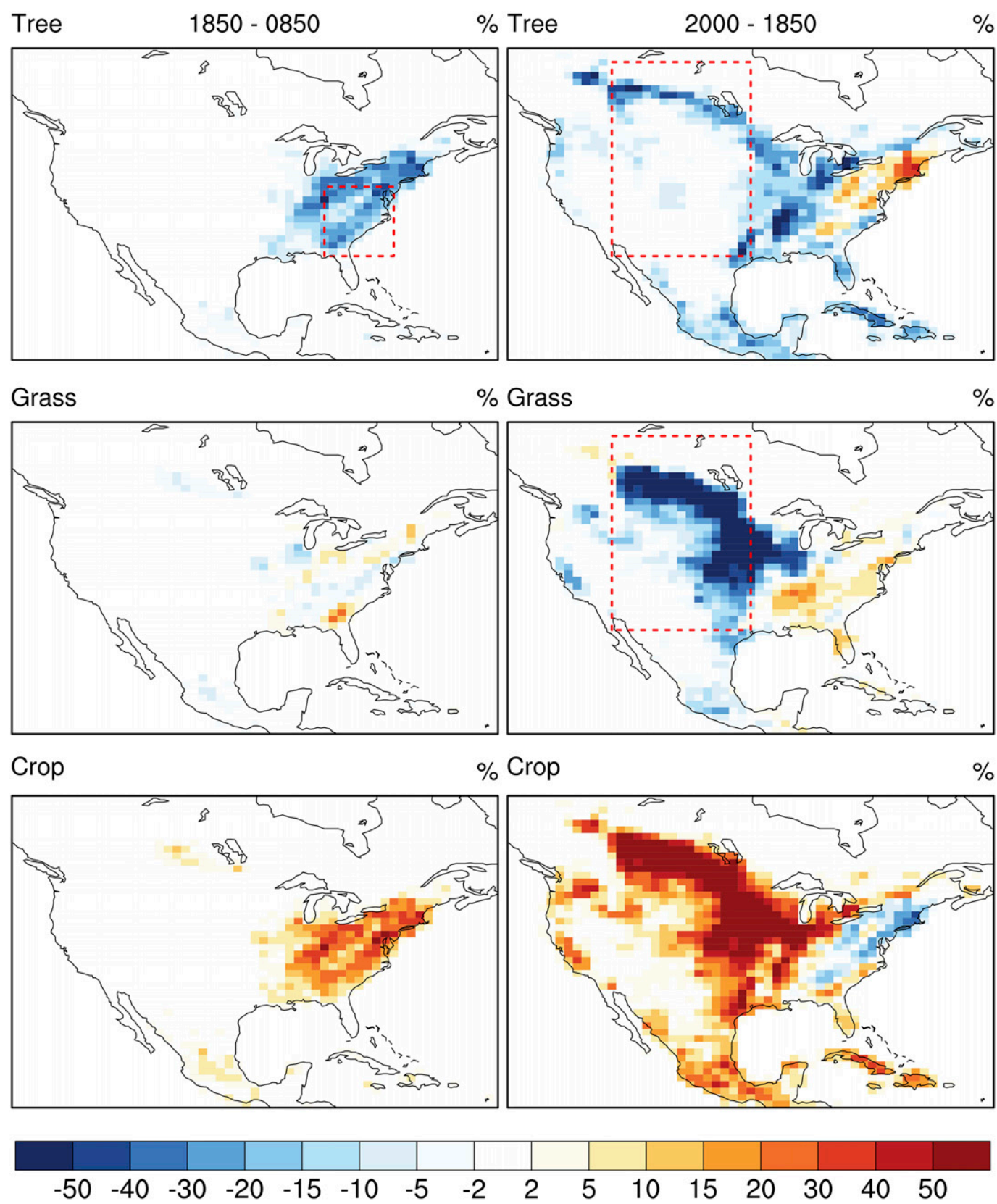

FIG. 1. Changes (\% of each grid) in three major plant functional types (PFTs) (left) from 850 to 1850 and (right) from 1850 to 2000. Dashed red boxes are used to identify the two subregions for examination of soil moisturesurface fluxes-atmosphere relationship.

atmospheric conditions such as air temperature, boundary layer height, or the occurrence and intensity of precipitation (Dirmeyer et al. 2014a).

A novel aspect of this study is the focus on landatmosphere interactions that occur within the diurnal cycle. Using hourly model output, local morning (09001200 LT) and local afternoon (1300-1800 LT) are identified for each grid cell so that day-to-day fluctuations in the impacts of morning land surface conditions on morning fluxes and then afternoon atmospheric characteristics can be investigated. For instance,

$$
\mathrm{CS}_{L}=\operatorname{corr}(\mathrm{SM}, \mathrm{LH}) \sigma_{\mathrm{LH}}
$$

is a coupling strength for the terrestrial leg, where corr indicates the temporal correlation between morning top-10-cm soil moisture SM and morning surface latent heat flux $\mathrm{LH}$, and $\sigma_{\mathrm{LH}}$ is the temporal (day to day) 
TABLE 1. Land-cover change experiments in CESM.

\begin{tabular}{ccl}
\hline \hline Name & Atmosphere & \multicolumn{1}{c}{ Land cover } \\
\hline 2000 & CAM4 & Present PFTs (2000) \\
1850 & CAM4 & Preindustrial PFTs (1850) \\
0850 & CAM4 & Last-millennium PFTs (0850) \\
\hline
\end{tabular}

standard deviation of LH. Sensible heat flux SH can be easily substituted for LH. Similarly,

$$
\mathrm{CS}_{A}=\operatorname{corr}(\mathrm{LH}, \mathrm{CAPE}) \sigma_{\mathrm{CAPE}}
$$

in which $\mathrm{CS}_{A}$ is one of the coupling strength metrics for the atmosphere leg, showing the linkage between morning LH and afternoon CAPE.

By applying such metrics to a high-resolution reanalysis, Wei and Dirmeyer (2012) found that over 90\% of the ET-precipitation coupling strength is from the local impacts, and the local impacts should be more predominant for lower-resolution grids (in this study, for instance). Therefore, these metrics should well demonstrate the sensitivity of locally initiated afternoon precipitation to the morning surface conditions.

\section{e. Afternoon precipitation}

In the analysis of the probability of afternoon precipitation, days with morning precipitation are excluded so that the influence of long-duration stratiform rainfall events can be minimized (Findell et al. 2011). Locally triggered afternoon convective precipitation is defined with two criteria: 1) afternoon rainfall is greater than $1 \mathrm{~mm}$, and 2) CAPE in the afternoon is greater than $70 \mathrm{~J} \mathrm{~kg}^{-1}$ so that convection should be triggered (Suhas and Zhang 2014). The sensitivity of afternoon precipitation frequency to morning land surface conditions (such as latent heat flux) is calculated with the coupling strength metric in section $2 \mathrm{c}$ expressed in terms of the slope of linear regression (cf. Dirmeyer 2011):

$$
S=\sigma_{\mathrm{LH}} \frac{\partial \Gamma(\text { rain })}{\partial \mathrm{LH}},
$$

in which the distribution of morning LH is split into 10 bins with an equal number of data points in each bin, $\Gamma$ (rain) is the probability of afternoon rainfall satisfying the two criteria above for each LH bin. Binning helps reduce the impact of spurious outliers on the regression.

Furthermore, calculating the sensitivity of afternoon precipitation intensity follows as

$$
S=\sigma_{\mathrm{LH}} \frac{\partial(\mathrm{RAIN})}{\partial \mathrm{LH}},
$$

in which RAIN is the rainfall amount of all events satisfying those two criteria for locally triggered afternoon convective precipitation. Sensitivity relationships can be similarly calculated between other variables using the same procedure.

\section{Results}

\section{a. Changes in surface properties}

Figure 2 shows the changes in JJA surface properties within the two land-cover change scenarios. Surface albedo is an indicator of the land surface's ability to absorb solar radiation, which is the ultimate driver of the energy cycle. Leaf area index (LAI) is strongly related to transpiration and canopy interception that are critical aspects of the role of vegetation in the surface water cycle. Aerodynamic resistance is inversely related to the overall roughness of the surface and thus its ability to generate mechanical mixing that aids both latent and sensible heat fluxes.

Surface albedo and aerodynamic resistance increases across the deforested regions; meanwhile LAI decreases over the same regions. From 1850 to the present, crops replaced grassland over much of the Great Plains, where there is slightly decreased albedo and aerodynamic resistance but no appreciable change in LAI. The reforested regions in the northeastern United States show a slight decrease in surface albedo and aerodynamic resistance and an increase in LAI during summer. Generally speaking, agricultural expansion has different, largely opposing, net effects on surface physical properties depending on whether the natural vegetation is forest or grassland.

\section{b. Changes in surface fluxes}

Land-cover changes can modify the partitioning within the surface energy budget. Figure 3 shows SH and $\mathrm{LH}$ in the morning after land-cover change. Mean morning SH and $\mathrm{LH}$ with the present land-cover conditions are shown in Fig. S2 of the supplementary material for comparison. With land-cover changes from 850 to 1850 , SH decreases over the eastern United States after the forest is replaced with cropland. It should be noted that over the central and southwestern United States there is no land-cover change during this period; nevertheless there are significant increases in sensible heat flux. From 1850 to 2000, there is significantly decreased SH over the Great Plains and an increase in the eastern United States. Generally, land-cover change from forests to croplands decreases SH because croplands are aerodynamically smoother than forest and transfer heat less effectively (Chen and Dirmeyer 2016). There is also significantly increased LH over the regions converted to crops (Fig. 3d), which further contributes 

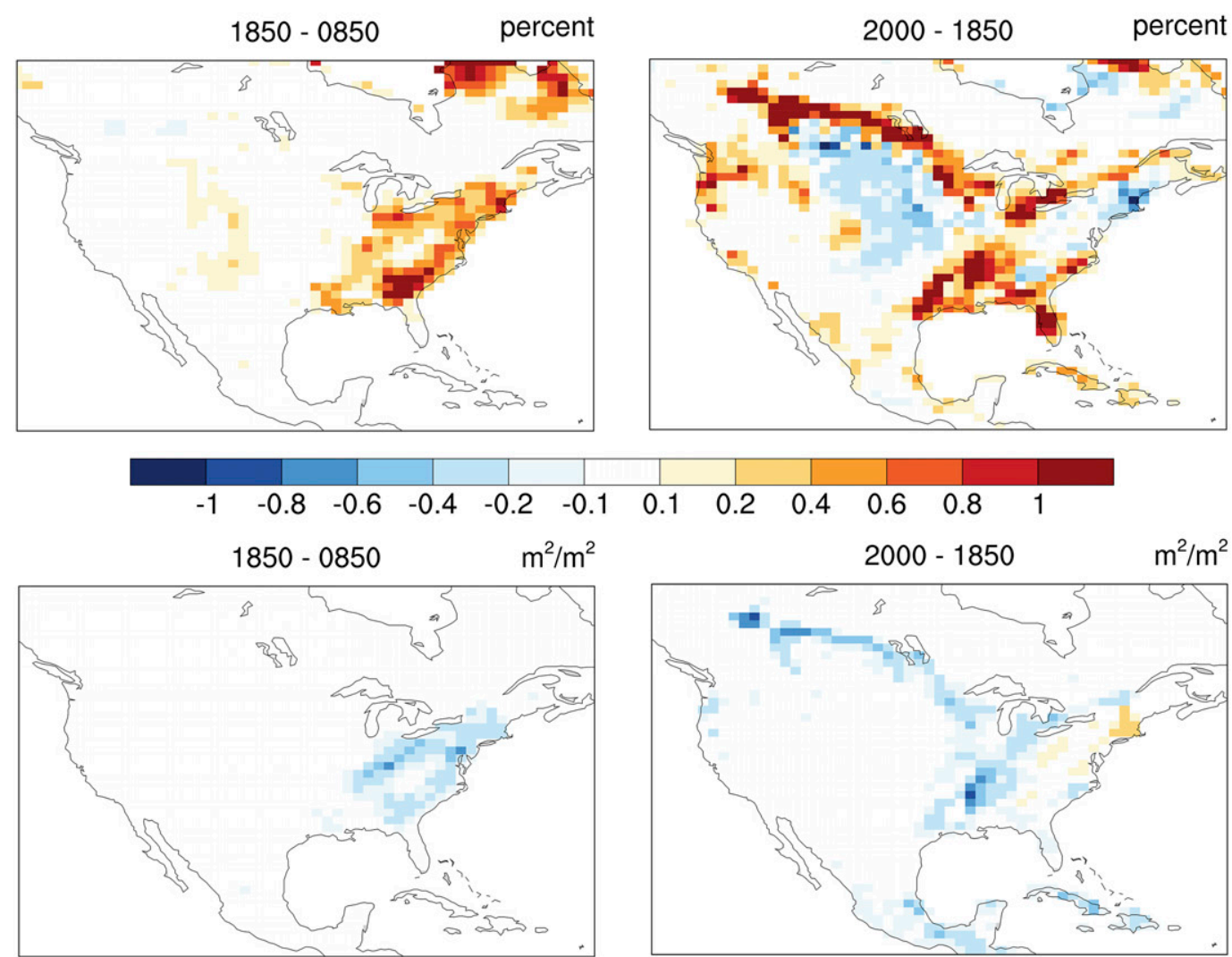

$\begin{array}{llllllllllll}-1 & -0.8 & -0.6 & -0.4 & -0.2 & -0.1 & 0.1 & 0.2 & 0.4 & 0.6 & 0.8 & 1\end{array}$

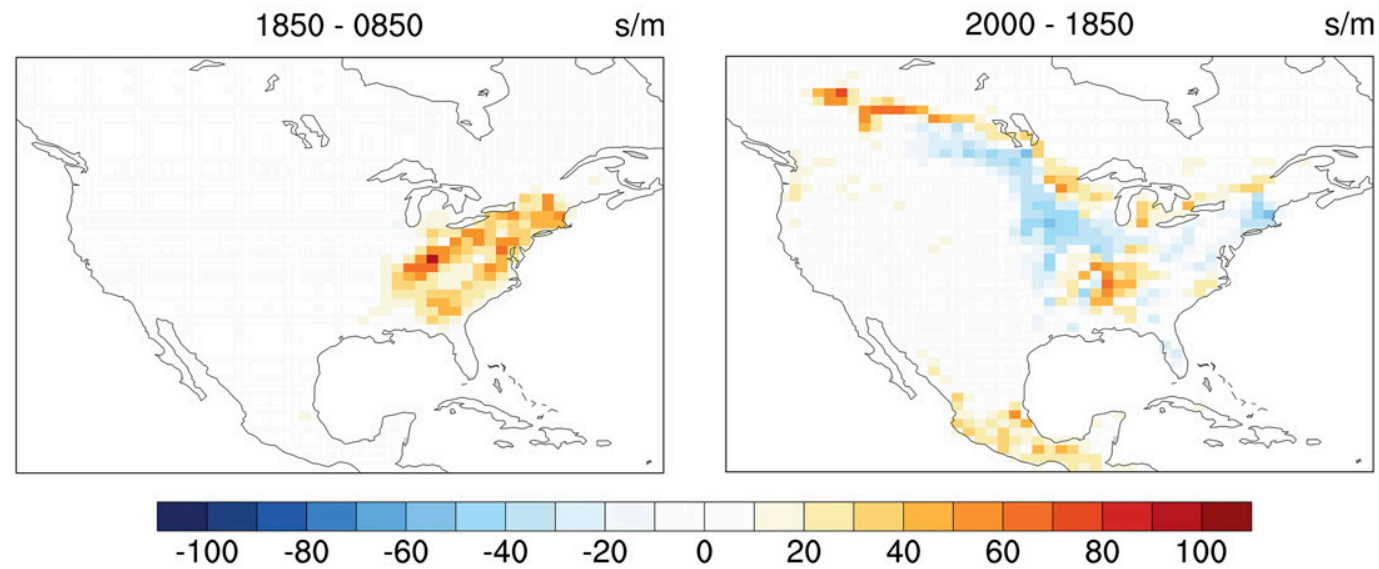

FIG. 2. Changes in (top) surface albedo, (middle) LAI, and (bottom) aerodynamic resistance during JJA; units as indicated above each panel.

to the decreased SH when evaporative fraction increases as crops transpire more freely than forest.

To evaluate the robustness of these surface flux changes, especially over the regions without land-cover change, we compare the monthly results from the first ensemble with the ensemble average (Figs. S3 and S4 in the supplementary material). Generally, changes in monthly averaged surface fluxes in the first ensemble member (Fig. S3) show consistent spatial patterns with the changes in morning-only surface fluxes but with a smaller magnitude because the fluxes are amplified during the daytime. There is also a good agreement over most regions (except the central United States) between the first member (Fig. S3) and the three-member average (Fig. S4), 

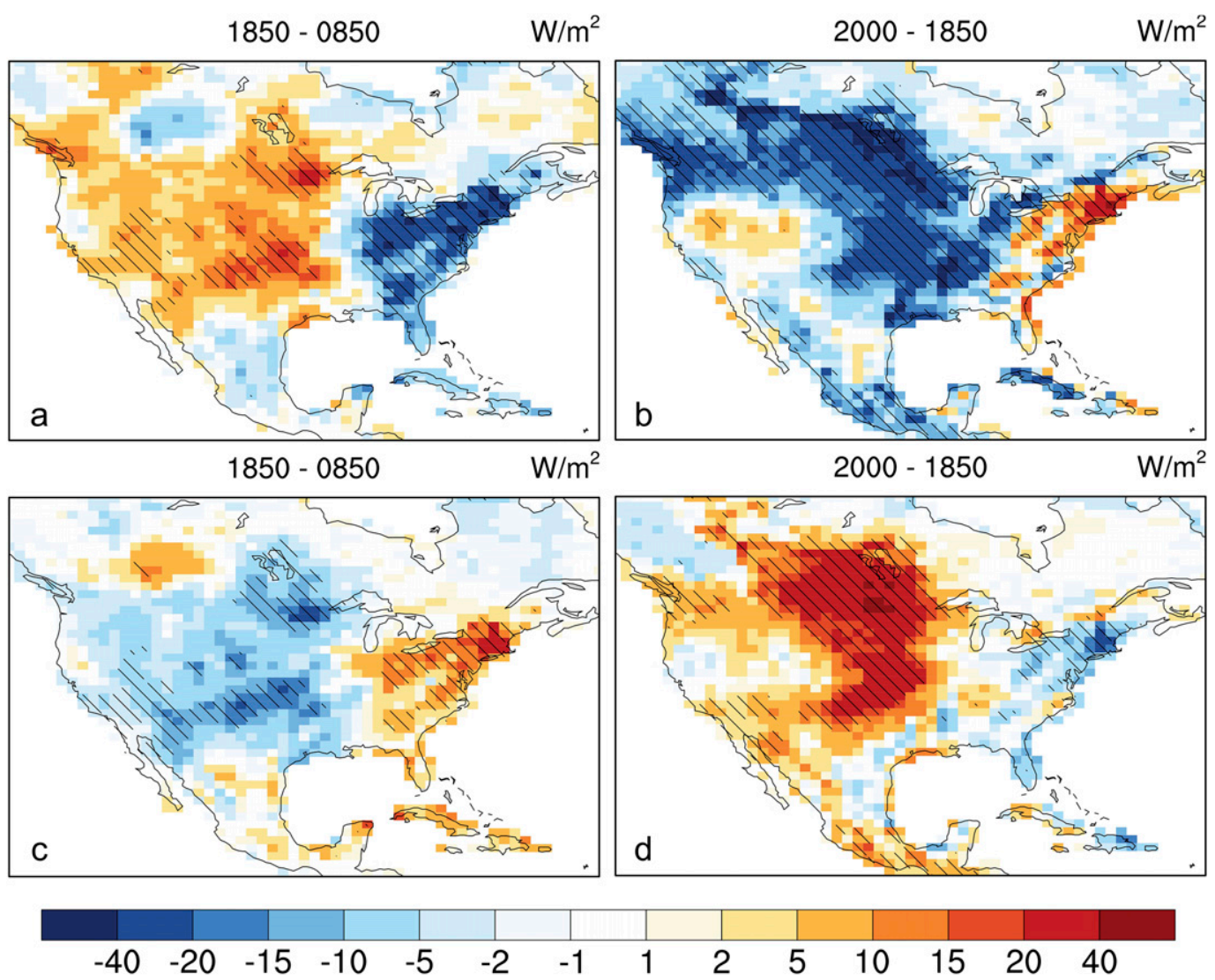

FIG. 3. Changes in morning (a),(b) surface SH and (c),(d) LH during JJA. Hatching indicates significance at the $95 \%$ confidence level.

indicating the robustness of land-change-induced changes over these regions. On the other hand, there is discrepancy in the magnitude of flux changes and the signal over the central United States in the ensemble average, which may arise from the internal variability of the model.

Figure 4 shows the changes in the three major components of daily ET (evaporation of water intercepted by the canopy, canopy transpiration, and soil evaporation) within the two land-cover change scenarios. We note that the daily ET change exhibits almost the same spatial pattern as the afternoon ET. Therefore, its components, which were not output hourly for these coupled simulations, are still explanatory for the afternoon surface latent heat flux change. The change in canopy evaporation corresponds well to the change in LAI caused by deforestation or reforestation (Fig. 2). For instance, we find a significant decrease in canopy evaporation over the deforested regions in the central United States and Canada and increased canopy evaporation over the later reforested regions in the northeastern United States. Over the Great Plains, no obvious change in canopy evaporation is found because of the similar LAI between crops and grass during summer. However, there are significantly increased canopy transpiration and ground evaporation in deforested regions. Crops tend to have lower minimum stomatal resistance and a greater propensity to transpire moisture across a range of soil moisture and environmental conditions. This has implications for the impacts of land-atmosphere coupling (soil moisture-surface fluxesatmosphere) over this region. Figure S5 in the supplementary material shows the changes in ET components from the ensemble average. Again, there are robust signals over the eastern U.S. areas that have undergone deforestation or reforestation, the Great Plains cropland expansion, and parts of the southwestern United States that did not experience land-cover change from 850 to 1850 . The decreased canopy transpiration in the first ensemble member over parts of the central United States from 850 to 1850 (Fig. 4) may arise from the internal variability of the model.

\section{c. Changes in afternoon precipitation}

Changes in summer afternoon precipitation are shown in Fig. 5. It should be noted that total precipitation (Figs. 5a,b) comprises both convective and large-scale precipitation. The changes in total precipitation are mostly due to changes in convective 

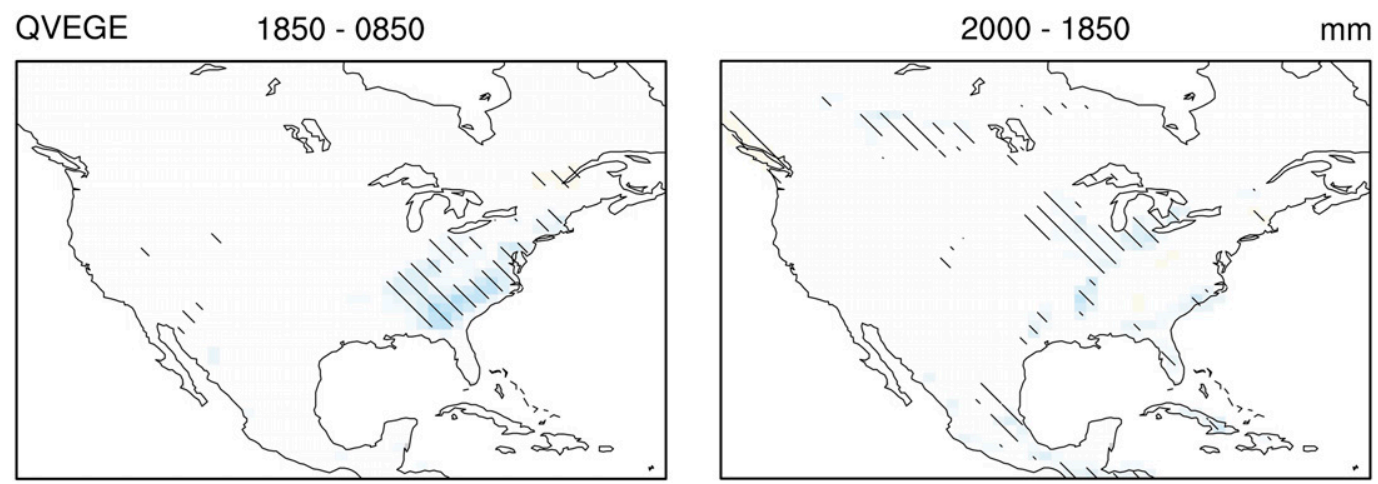

QVEGT
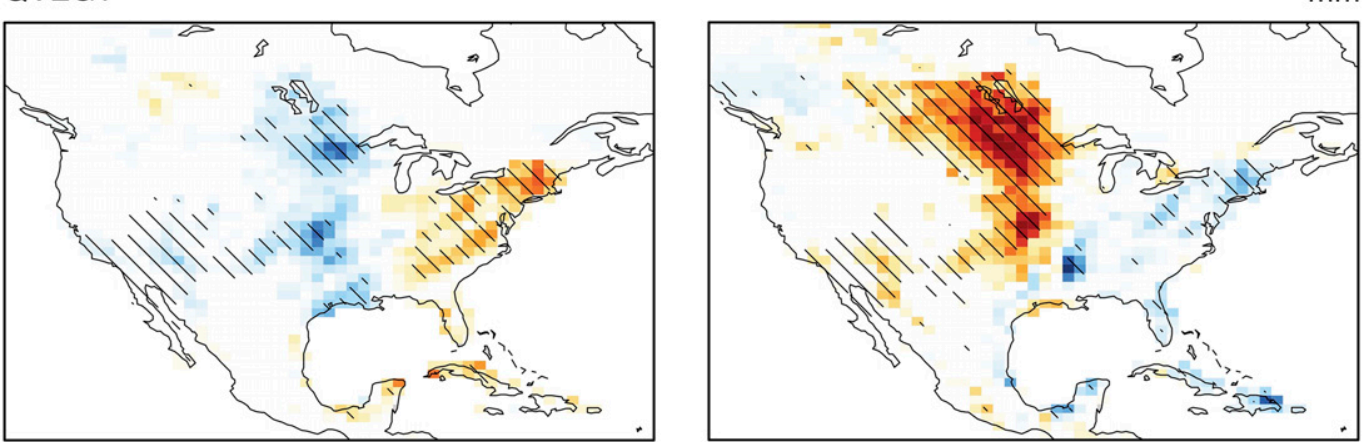

QSOIL
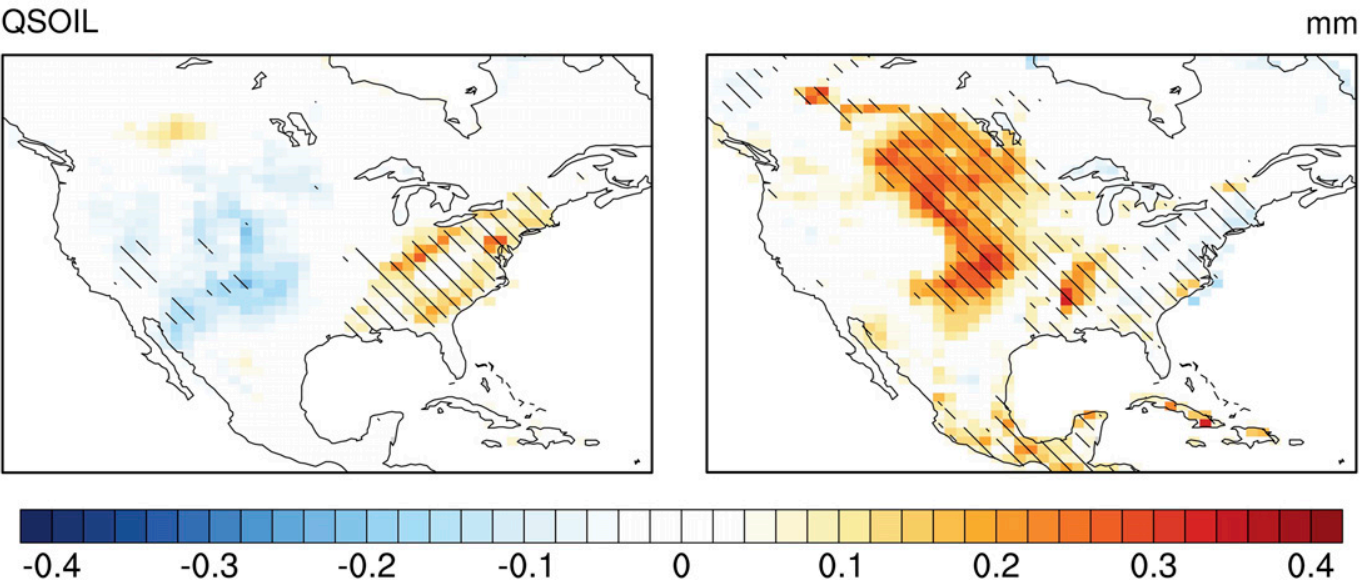

FIG. 4. Changes in different components in ET during JJA. (top) Canopy evaporation (QVEGE), (middle) canopy transpiration (QVEGT), and (bottom) soil evaporation (QSOIL). Hatching indicates significance at the $95 \%$ confidence level.

precipitation (Figs. 5c,d), while there is generally much less change in large-scale precipitation (Figs. $5 \mathrm{e}, \mathrm{f}$ ). As a result of land-cover change from 850 to 1850 , there is a significant decrease in precipitation over the southeastern and parts of the southwestern United States, the latter area having experienced no land-cover changes in this interval. A significant decrease in afternoon precipitation is also found over parts of the central United States but is not discussed here because no robust signal is observed over this region in the ensemble average (Fig. S6 in the supplementary material). Previous studies have suggested that in humid regions, soil moisture is not a controlling factor for ET, but energy limits the land-atmosphere interactions (e.g., Seneviratne and Stöckli 2008). Therefore, over the eastern United States where deforestation occurred prior to 1850 , decreased afternoon precipitation may be explained by reduced sensible heat flux (Fig. 3) from the land surface, which is further discussed in section $3 \mathrm{~d}$. Figure $5 \mathrm{~b}$ shows the afternoon precipitation difference between 1850 and present land-cover conditions. Afternoon precipitation significantly increases over the Great 

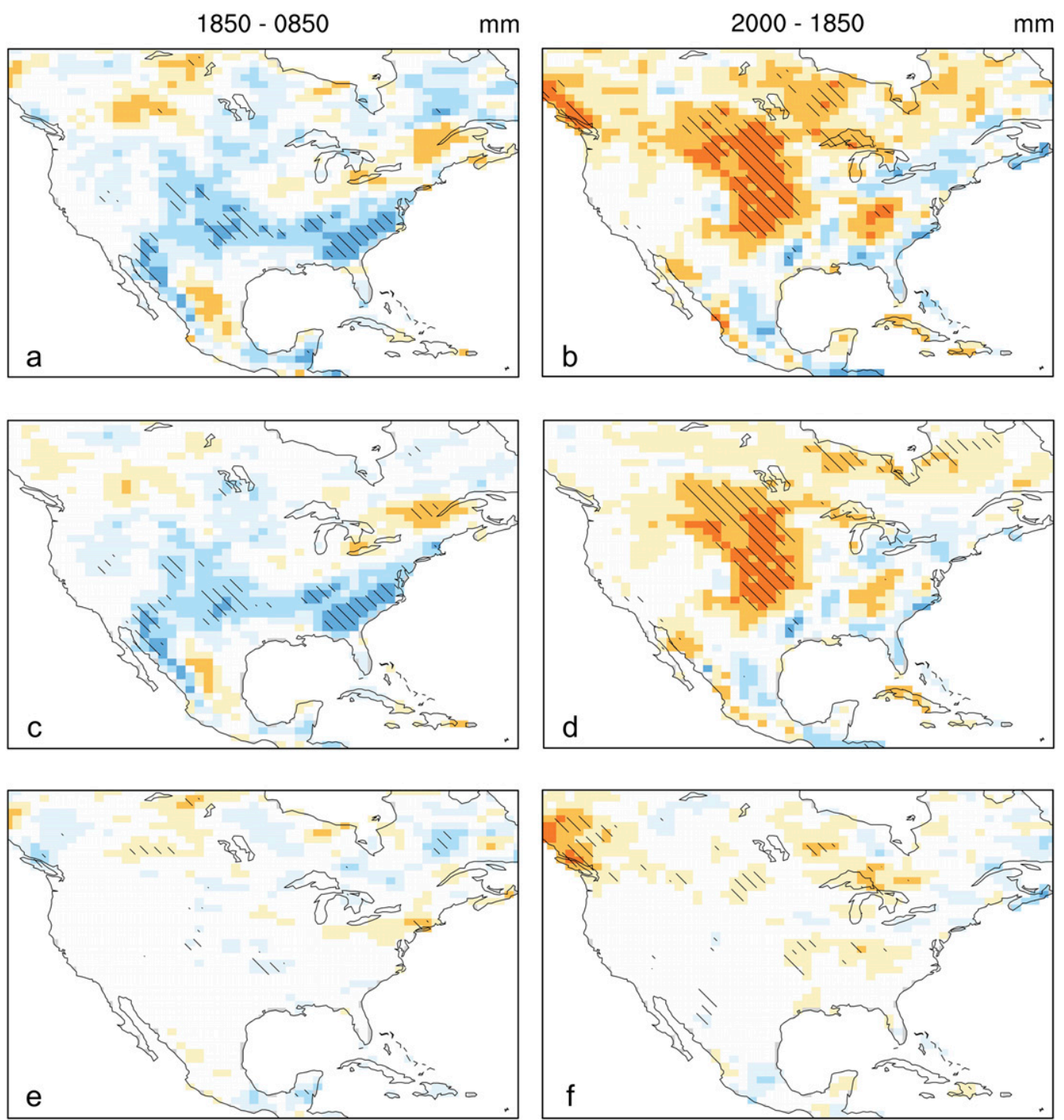

\section{$\begin{array}{llllllllll}-0.5 & -0.25 & -0.1 & -0.05 & -0.02 & 0.02 & 0.05 & 0.1 & 0.25 & 0.5\end{array}$}

FIG. 5. Changes in total (a),(b) afternoon precipitation, (c),(d) convective precipitation, and (e),(f) large-scale precipitation during JJA. Hatching indicates significance at the $95 \%$ confidence level.

Plains. The increased latent heat flux due to agriculture can "pump" more moisture into the atmosphere to trigger precipitation in this more semiarid region where there is a positive feedback in the water cycle in climate models (e.g., Dirmeyer et al. 2013). It should be noted that the spatial pattern of afternoon precipitation change shows good agreement with the change in top-10-cm soil moisture (Fig. S7 in the supplementary material), indicating its strong coupling with precipitation, either as the cause or as the effect of precipitation change.

There are two ways for the increased precipitation to occur: increased rainfall frequency or increased rainfall intensity. Figures $6 \mathrm{a}$ and $6 \mathrm{~b}$ show the changes in the number of days with afternoon precipitation greater than $1 \mathrm{~mm}$. The threshold is chosen to avoid the prevalent drizzle issue common to many GCMs (e.g., Dai 2006; Findell et al. 2011; Taylor et al. 2012). Our results show little qualitative sensitivity to the specific value of the minimum threshold; the spatial pattern changes little although the count is influenced. Overall, the changes in afternoon precipitation frequency show very good agreement with total precipitation. However, the changes in the average intensity of precipitation events greater than $1 \mathrm{~mm}$ (Figs. $6 \mathrm{c}, \mathrm{d})$ do not show much agreement with 

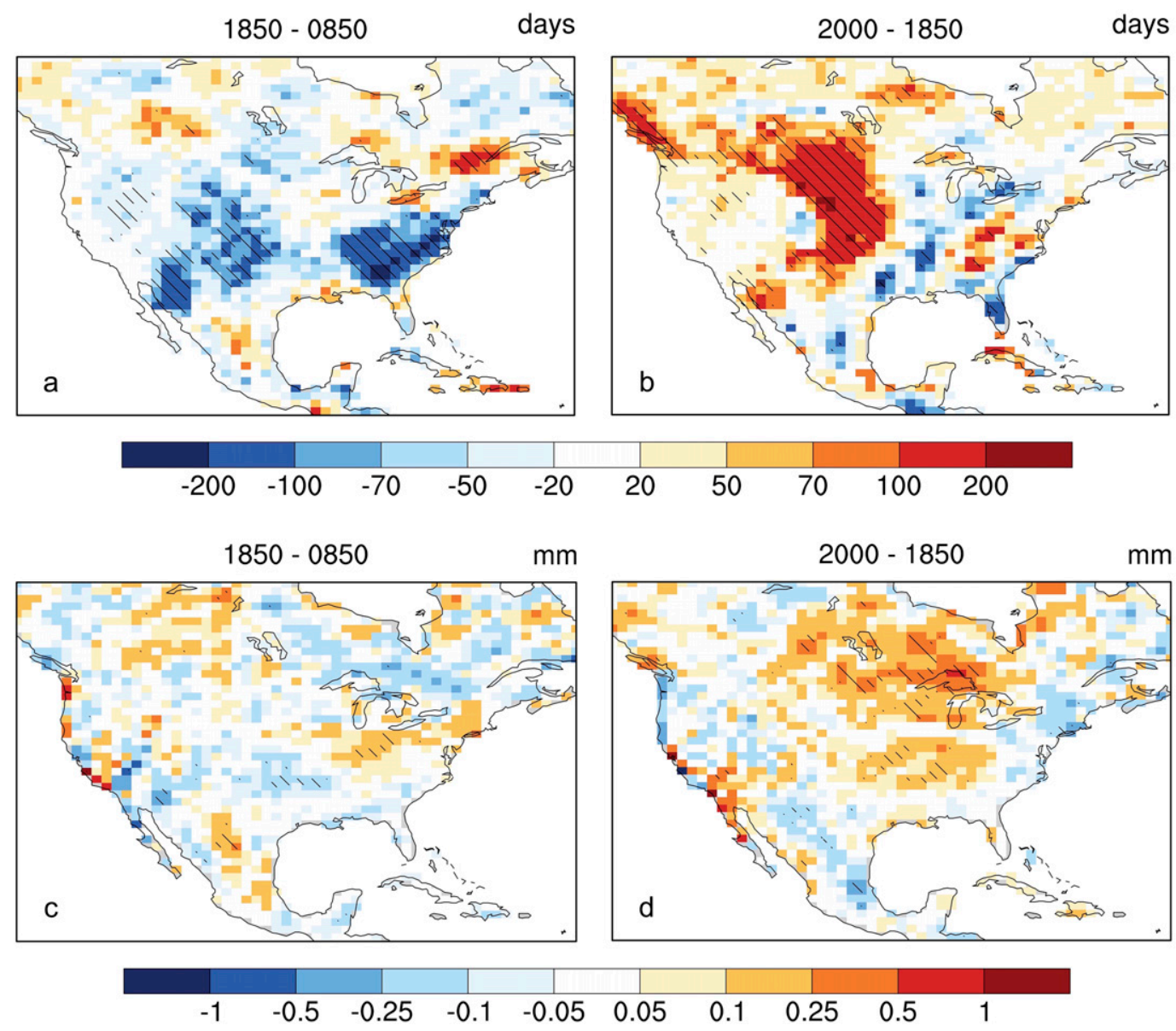

FIG. 6. Changes in (a),(b) frequency and (c),(d) intensity of afternoon precipitation ( $>1 \mathrm{~mm}$ ) during JJA. Values are means from 2000 bootstrap samples (with replacement). Hatching indicates significance at the $95 \%$ confidence level from 2000 bootstrap samples.

Fig. 5 nor much significant change compared with frequency. Therefore, the changes in precipitation after land-cover change are attributable to changes in the frequency of afternoon rainfall. With the land-cover change from 850 to 1850 , the frequency of afternoon precipitation would decrease by $6.6 \%$, while with the landcover change from 1850 to 2000 , the frequency would increase by $7.6 \%$ (the calculation is based on the grid cells with significant change in Figs. 6a,b). Our results are consistent with those of Findell et al. (2011) and Berg et al. (2013), who suggested that morning evaporative fraction has significant impacts on afternoon rainfall probability but not on the rainfall amount. Combined with the result showing changes are predominantly in convective precipitation, this suggests that the mechanism influencing the change in precipitation must be affecting the triggering of convection in the model.

To further explore the mechanism driving afternoon precipitation frequency changes, two subregions are identified (within the dashed red boxes in Fig. 1). The first subregion is defined as the grid cells within the box over the southeastern United States having more than $10 \%$ change from trees to cropland from 850 to 1850 . The second subregion is defined within the larger Great Plains box as grid cells with over $10 \%$ change to cropland from grass between 1850 to 2000. Figure 7 shows the relationship between afternoon CAPE and precipitation over the two subregions. Not surprisingly, afternoon precipitation in CAM is strongly positively correlated with CAPE. In Fig. 7a, both CAPE and precipitation decrease after land-cover change from trees to crops over the southeastern United States. The leftward shift of the CAPE probability density function (PDF) curve shows more days with low CAPE (less than $70 \mathrm{~J} \mathrm{~kg}^{-1}$; indicated by a vertical gray dotted line in the PDF plots) over cropland than that over forests, which indicates that fewer days have afternoon convective precipitation triggered, leading to decreased afternoon 

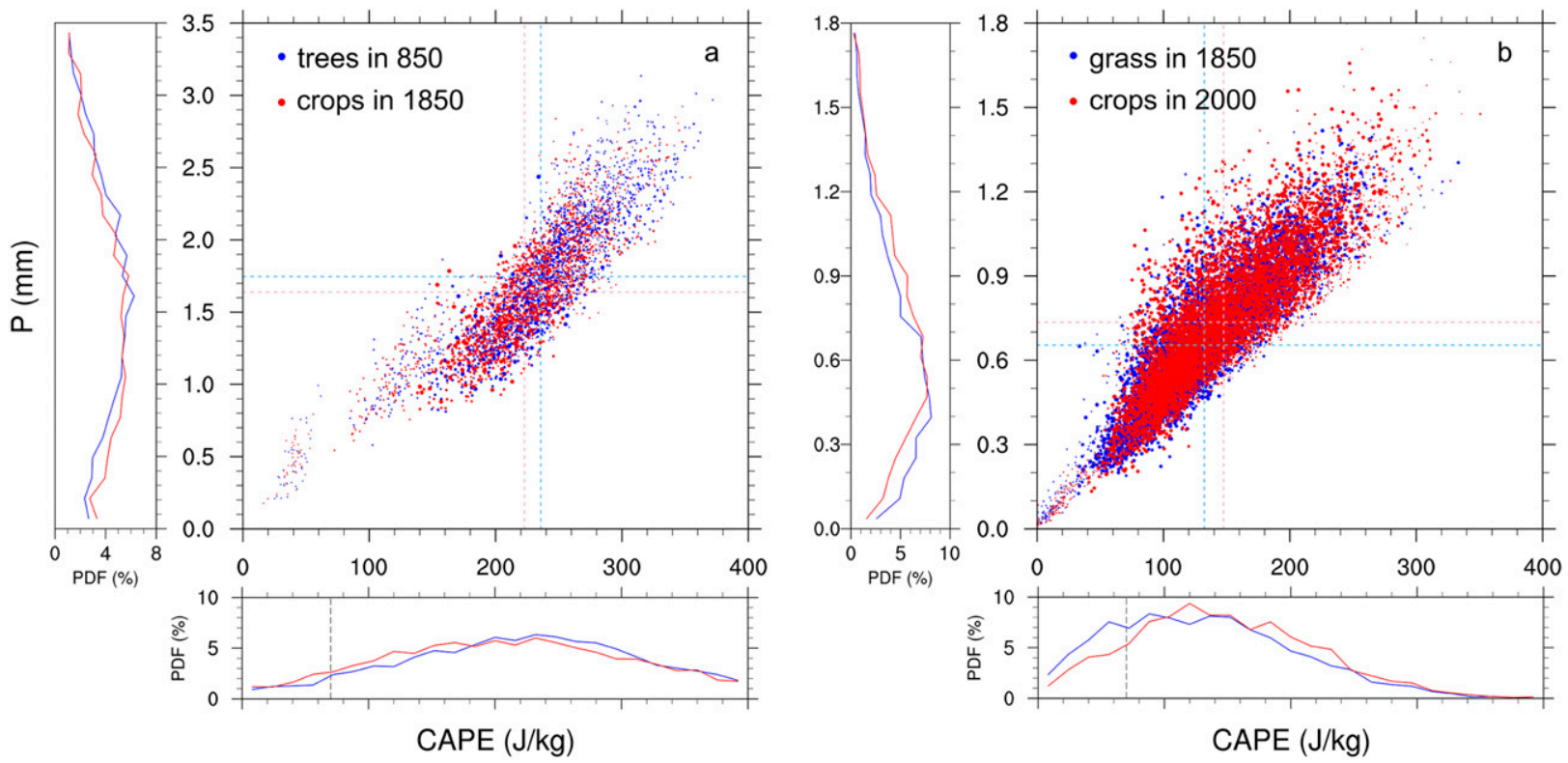

FIG. 7. Relationship between afternoon CAPE and precipitation, and the PDF of CAPE and precipitation in the two subregions. (a) Grid cells $(N=48)$ with over $10 \%$ change from trees to crops over the southeastern United States from 850 to 1850 ; (b) grid cells $(N=$ 212) with over $10 \%$ change from grass to crops over the Great Plains from 1850 to 2000. In the scatterplot, each dot represents the averaged JJA afternoon value at each grid cell in each year (from 40-yr simulations with each land-cover scenario), blue for original vegetation, red for crops. Crosshairs indicate the mean of each variable. The vertical gray dotted line in the PDF of CAPE indicates the CAPE-based convective trigger $\left(70 \mathrm{~J} \mathrm{~kg}^{-1}\right)$.

precipitation over this region. Figure $7 \mathrm{~b}$ shows an opposite shift in CAPE and precipitation after land-cover change from grass to crops over the Great Plains. There are fewer days with low CAPE, more days with convective precipitation triggered, and increased afternoon precipitation over cropland. Such a CAPE-precipitation relationship demonstrates the response of afternoon precipitation frequency to changes in atmospheric stability caused by land-cover changes. As CAPE is the trigger in the model convective parameterization, whose change also exhibits very good agreement with precipitation change (Fig. S8 in the supplementary material), this establishes the cause in the changes of precipitation frequency in the last link of the process chain connecting land-cover change to rainfall change.

\section{d. Land-atmosphere coupling strength}

Having established strong linkages between land-cover change and surface fluxes, as well as between precipitation changes and atmospheric stability that is the basis for triggering rainfall, we use metrics of land-atmosphere coupling strength to make the middle link between surface flux changes and atmospheric stability changes.

Figure 8 shows the atmospheric leg of coupling strength between latent (sensible) heat flux in the morning and CAPE (PBL height) in the afternoon in the 2000 experiment (the terrestrial leg of coupling strength between soil moisture and surface fluxes is shown in Fig. S9 of the supplementary material). The PBL height is chosen because it is also related to convective triggering. SH and PBL height are positively correlated everywhere over land as $\mathrm{SH}$ is the primary source of warming at the bottom of the troposphere, which grows the daytime boundary layer. LH coupling with CAPE is large mainly over the western United States as well as over Canada and New England. Both show strong coupling strength overlapping in the Great Plains, indicating morning land surface conditions may strongly influence afternoon rainfall over this region by either pathway. Here CAPE is strongly correlated to variations in $\mathrm{LH}$, even though the greatest mean values of CAPE are along the Gulf Coast (not shown).

The overall positive correlation of PBL height to SH, and by extension a widespread negative correlation with top-10-cm soil moisture as inferred from Fig. S3, is consistent with the strong inverse relationship between soil moisture and PBL growth via SH described by Betts (2004). Large-scale atmospheric conditions may play a more important role over those regions where coupling strength is relatively weak, such as the eastern United States (cf. Findell and Eltahir 2003). Such a positive coupling between SH and PBL could be a contributing factor to the decreased precipitation with land-cover changes from 850 to 1850 over the eastern United States. 
LH and CAPE

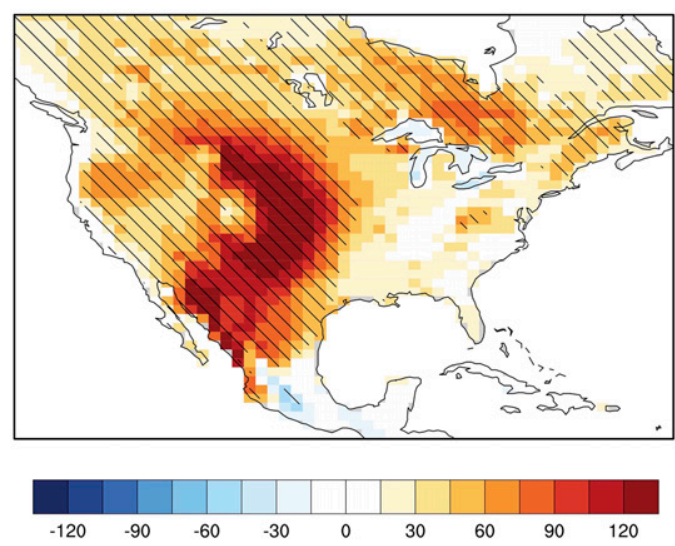

$\mathrm{J} / \mathrm{kg} \quad \mathrm{SH}$ and PBL height

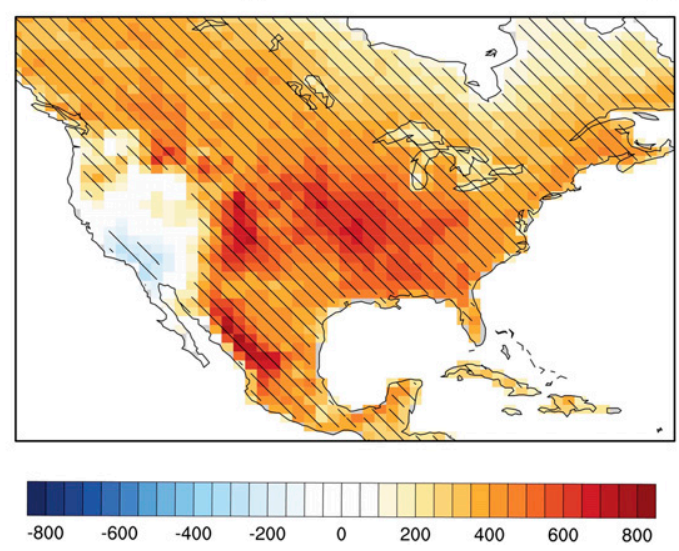

FIG. 8. Atmospheric segments of coupling strength (left) between morning LH and afternoon CAPE and (right) between morning SH and afternoon PBL height during JJA. Hatching indicates significance at the $95 \%$ confidence level.

The increased morning LH (Fig. 3) is not followed by increased afternoon precipitation (Fig. 5). On the contrary, the decreased morning SH leads to lower air temperatures in the afternoon (Fig. S10 in the supplementary material), which can inhibit PBL growth and the triggering of convection, leading to decreased afternoon precipitation.

To further explore the PBL-related precipitation change over the eastern United States, the metric LCL deficit is used to quantify the tendency toward saturation in the PBL. The LCL deficit is defined as the difference between PBL and LCL height (Santanello et al. 2011b). The change of daily averaged PBL height, LCL, and LCL deficit in the land-cover change from 850 to 1850 experiment (Fig. S11 in the supplementary material) indicates the PBL deficit increases owing to significant decreased PBL height (higher pressure indicates shallower PBL in the figure), indicating less sufficient lift and condensation for cloud formation and precipitation.

Both land and atmosphere segments indicate strong positive feedbacks within the soil moisture-precipitation coupling framework in the water cycle (soil moistureET-precipitation trigger) over the Great Plains. Figure 9 shows the sensitivity of afternoon precipitation to morning LH and soil moisture by using Eqs. (3) and (4). Afternoon precipitation probability is readily linked to LH (or soil moisture) variations over the Great Plains and northern Mexico. This can well explain the more frequent afternoon precipitation over the Great Plains induced by landcover change from 1850 to 2000. Also, it is worthwhile to note the difference between soil moisture-precipitation coupling (Fig. 9a) and the LH-precipitation coupling (Fig. 9b). Over the eastern United States and particularly Canada, precipitation probability is sensitive to surface fluxes but not to soil moisture. This difference reiterates that the land-atmosphere interactions over this region are limited to the atmospheric segment (Fig. S8a). Therefore, in spite of significant land surface changes over the eastern United States from 0850 to 1850 (or from 1850 to 2000), the change in afternoon precipitation does not show a uniform pattern (or is not significant; Fig. 5) except over parts of the Southeast. Additionally, afternoon rainfall intensity is not very sensitive to either soil moisture or latent heat flux, as no strong coherent patterns emerge (Figs. 9c,d). There is some tendency for a positive sensitivity over the Great Plains, in contrast to other areas that are very noisy, but it is not statistically significant. These results further reinforce the result in section $3 \mathrm{~d}$ that land-cover-induced afternoon rainfall changes are determined by occurrence of rainfall rather than its magnitude.

Under the backdrop of land-atmosphere coupling, we examine the evolution of the relationship between morning surface fluxes and afternoon CAPE in the two subregions delineated previously so that their afternoon precipitation changes can be explained (Fig. 10). Over the southeastern United States with deforestation, the increased $\mathrm{LH}\left(+7 \mathrm{~W} \mathrm{~m}^{-2}\right)$ and decreased SH $\left(-21 \mathrm{~W} \mathrm{~m}^{-2}\right)$ lead to overall decreased afternoon CAPE $\left(-13 \mathrm{~J} \mathrm{~kg}^{-1}\right)$, which is accompanied by less afternoon precipitation. On the other hand, the Great Plains with land cover changed from grass to crops shifts toward even higher $\mathrm{LH}\left(+22 \mathrm{~W} \mathrm{~m}^{-2}\right)$ and greater CAPE $\left(+15 \mathrm{~J} \mathrm{~kg}^{-1}\right)$ in the context of the strong positive coupling strength.

Figure 11 shows the soil moisture-LH-precipitation shifts for each grid box in the two subregions and their shifts with land-cover change. In the grid cells with 

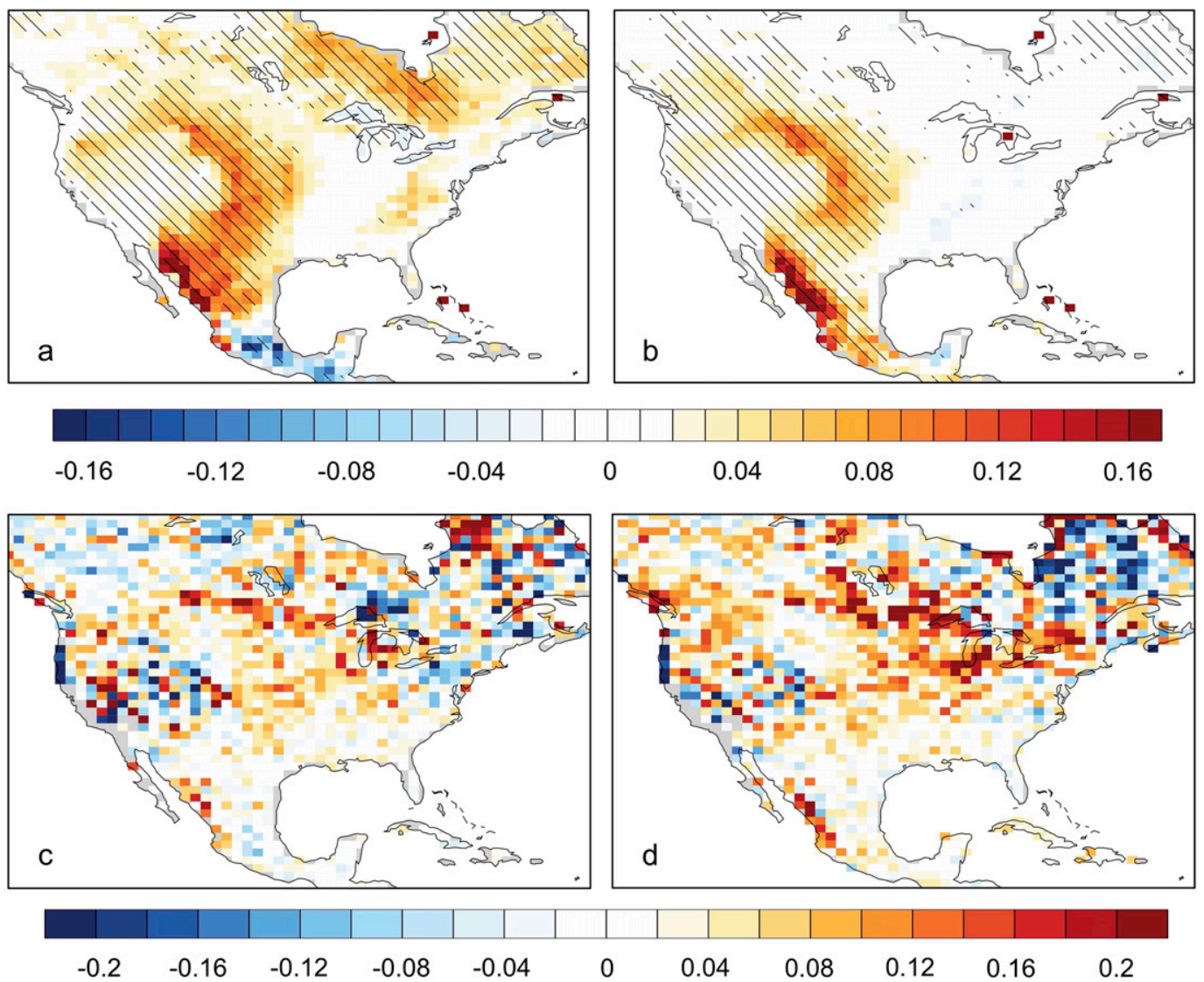

FIG. 9. Sensitivity of JJA afternoon precipitation to morning land surface conditions. (top) Sensitivity of afternoon precipitation probability (unitless) to morning (a) LH and (b) SM; (bottom) sensitivity of afternoon precipitation intensity (mm) to morning (c) LH flux and (d) SM.

land-cover change from trees to crops over the southeastern United States, the negative coupling at the land segment leads to increased morning LH but decreased soil moisture (Fig. 11a). Partitioning of available energy (which changes relatively little among the scenarios) between $\mathrm{LH}$ and $\mathrm{SH}$ leads to decreased morning $\mathrm{SH}$ in this region, explaining the decreased afternoon precipitation (Fig. 11c; cf. Figs. 3a,c). Over the Great Plains, the strong positive coupling of the land segment causes the grid cells to shift toward increased LH (Fig. 11b). On the other hand, in the atmospheric segment, a stronger and more consistent shift (parallel dashed lines) to greater precipitation is found over the grid cells with changes from grass to crops (Fig. 11d) because of the stronger coupling strength over this region (Fig. 9a) maintaining and slightly increasing soil moisture.

\section{e. Remote effects of land-cover change}

As in evidence for the water cycle in Fig. 11, the coupling is a two-way effect. In the hot spot region, not only does land significantly feed back upon the atmosphere, the changes in the atmosphere brought about by remote land-use changes also influence the local land surface. Deforestation in the eastern United States between 850 and 1850 has a local cooling effect at land surface concomitant with increased ET, which results in changes to the large-scale atmospheric circulation. Figure 12 shows the changes in geopotential height and winds at $500 \mathrm{hPa}$ during JJA from the threemember ensemble average. There are significantly decreased mean geopotential height anomalies and cyclonic wind anomalies over the northeastern United States after deforestation. We also find significantly decreased geopotential height and cyclonic wind anomalies over the southwestern United States where land-cover changes did not occur before 1850, which could explain the significantly decreased precipitation over parts of the southwestern United States. The large-scale circulation changes are congruous with a Rossby wave train response. In fact, the response seen in Fig. 12 is consistent with a positive land-atmosphere 

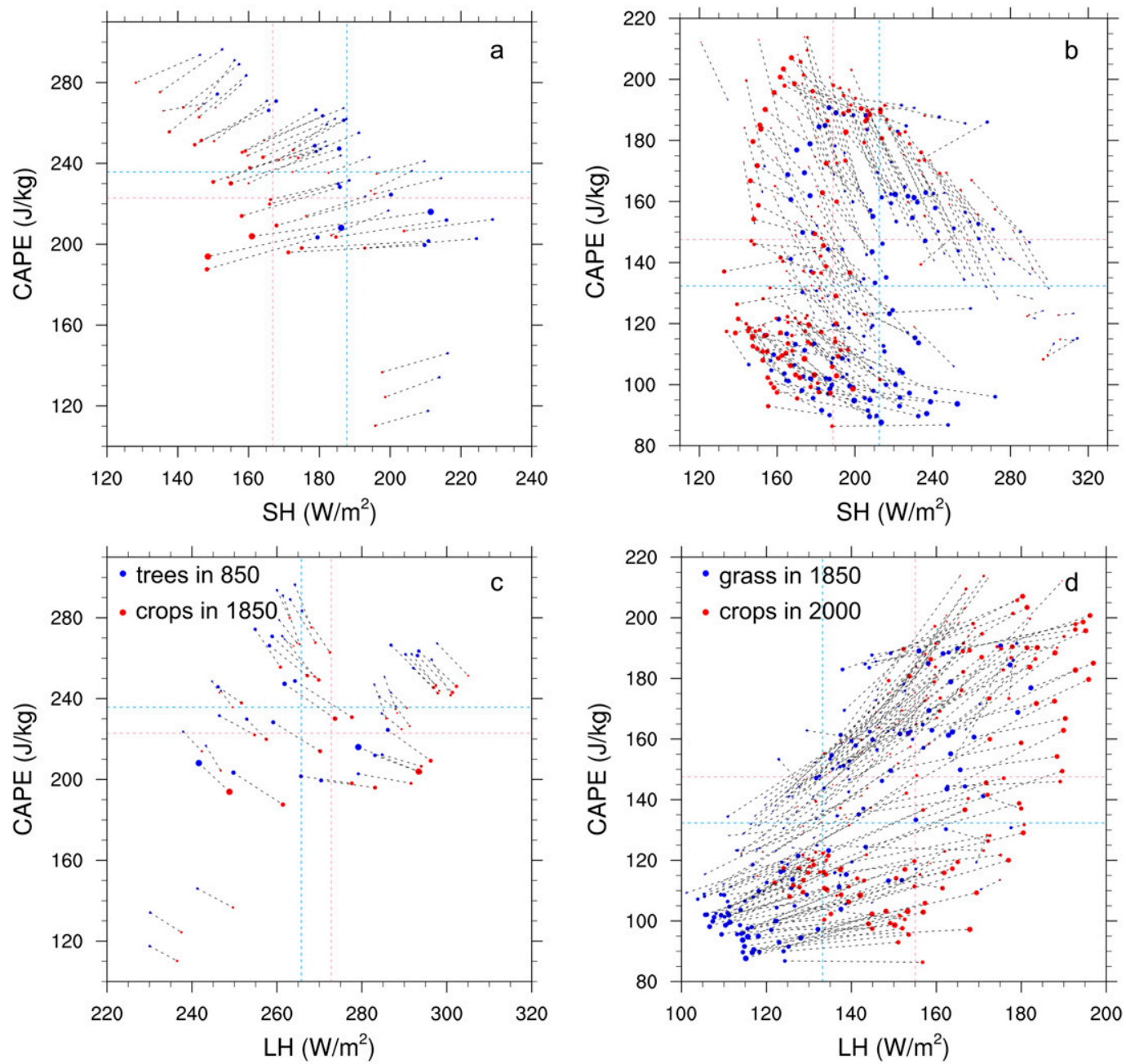

FIG. 10. Afternoon CAPE vs morning (a),(b) SH and (c),(d) LH in the two subregions. Dashed black lines connect each grid point before and after land cover change, indicated by the colors. Each dot represents the averaged JJA value at the grid cell over the 40-yr simulations. The sizes of the dots are proportional to the percentage change in crop cover. Crosshairs indicate the spatial mean of each variable for each land cover.

feedback over the southwestern United States, where decreased precipitation reduces latent heat flux and fewer convective events are triggered, sustaining the dry conditions. Contrast this to the different coupled response over the eastern United States, where conversion from forest to agriculture leads to opposite responses in surface fluxes than over the southwestern United States during this period but a similar decreased CAPE (Fig. S8), increased LCL deficit (Fig. S11), and reduced precipitation (Fig. 5). Reforestation over the eastern United States during the subsequent 150 years, when agriculture was abandoned over much of the region, may have induced the reverse response from the deforestation period that is likewise in phase with the U.S. Southwest response in Fig. 6 b. However, without more targeted sensitivity studies examining the two regional land-use changes separately this is speculation, as the response is convolved with the other remote land-use changes.

\section{Discussion}

In this study, strong land surface-precipitation coupling is found over the Great Plains, where afternoon precipitation shows high sensitivity to land-cover changes. This result agrees well with the identified hot spots of land-atmosphere interactions in the Global Land-Atmosphere Coupling Experiment (GLACE; Koster et al. 2004). Wei and Dirmeyer (2012) also found strong soil moisture-ET and ET-precipitation coupling strength over a similar region. However, the Great Plains hot spot clearly differs from the strong TFS 

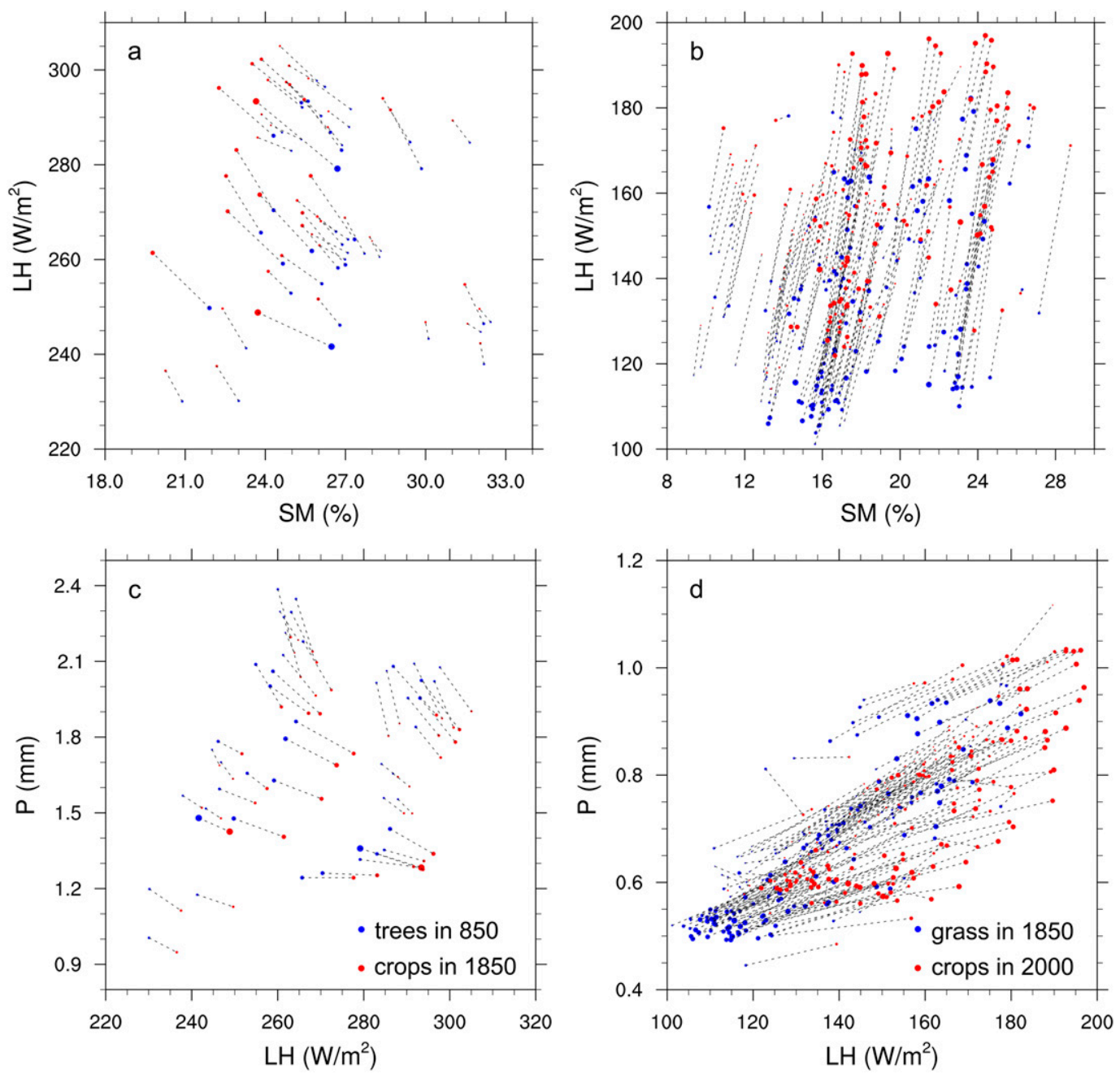

FIG. 11. (a),(b) Morning SM-morning LH and (c),(d) morning LH-afternoon precipitation relationship in the two subregions. Dashed black lines connect each grid point before and after land-cover change. Each dot represents the averaged JJA value over the 40-yr simulations at each grid cell. The sizes of the dots are proportional to the percentage change in crop cover.

located over the eastern United States by Findell et al. (2011) and Berg et al. (2013). This discrepancy may arise from the uncertainties within climate models (Guillod et al. 2014) or the large spread among different climate models (Koster et al. 2004). Another reason for the discrepancy could be the criteria used to identify potentially convective days. In this study CAPE is used to identify afternoon convection because it is used as a built-in threshold to trigger deep convection in CAM. TFS uses the convective triggering potential (CTP) and a low-level humidity index $\mathrm{HI}_{\text {low }}$ to distinguish convective events (Findell and Eltahir 2003). CTP is a measure of atmospheric stability, and $\mathrm{HI}_{\text {low }}$ is a measure of low-level humidity. This leads TFS to be atmospherically controlled (Guillod et al. 2014; Wei and Dirmeyer 2012) and low-level humidity dependent
(Aires et al. 2014). When applying the morning CTP and $\mathrm{HI}_{\text {low }}$ as criteria in calculating afternoon precipitation by using Eq. (3), where the afternoon CAPE $>70 \mathrm{~J} \mathrm{~kg}^{-1}$ criterion is replaced with morning $\mathrm{CTP}>0 \mathrm{~J} \mathrm{~kg}^{-1}$ and $5<\mathrm{HI}_{\text {low }}<15 \mathrm{~K}$ based on the CTP-HI ${ }_{\text {low }}$ framework (Findell and Eltahir 2003), the EF-precipitation probability relationship shows some consistency with the TFS map in Findell et al. (2011) and Berg et al. (2013), indicating a high coupling strength over the eastern United States and Mexico (Fig. 13). However, this cannot explain the precipitation response to land-cover change in our CESMbased experiments, particularly over the eastern United States before 1850 where the TFS metric suggests precipitation should have increased with ET. Instead, the accompanying cooling drives a decrease in 


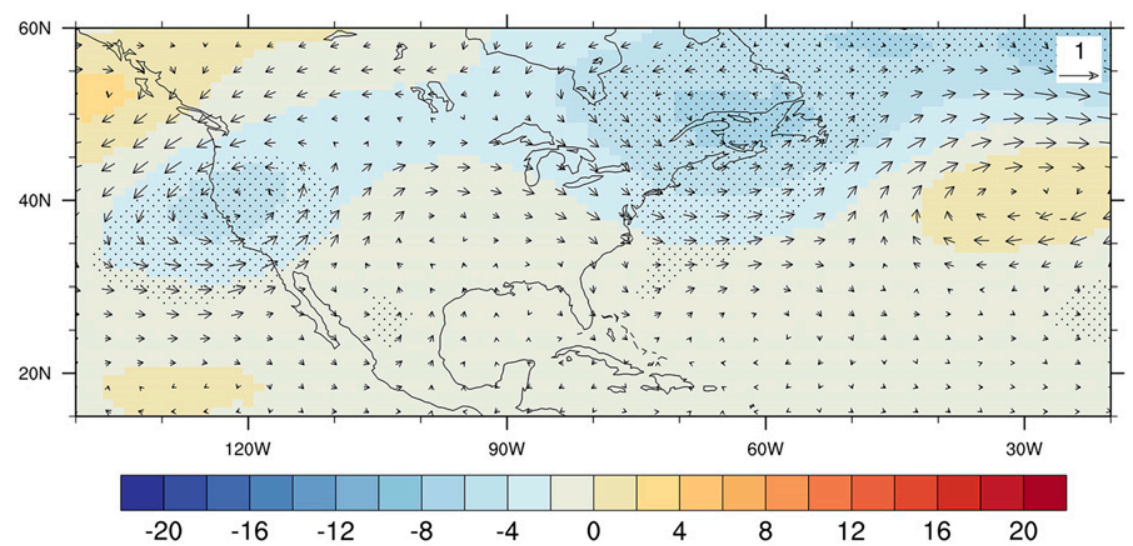

FIG. 12. Change in JJA geopotential height (shading; $\mathrm{m}$ ) and wind pattern (key vector indicates $1 \mathrm{~m} \mathrm{~s}^{-1}$ ) at $500 \mathrm{hPa}$ for experiments from 850 to 1850 .

CAPE and fewer rainfall events in CAM (Fig. 7). Furthermore, studies have shown that the local response of precipitation to the land surface state can be modulated by additional factors that vary in time within a season, determined by the preconditioned state of the atmosphere (e.g., Ford et al. 2015b; Song et al. 2016).

Meanwhile, there is a dominant positive relationship between morning soil moisture and afternoon precipitation, which is consistent with many previous studies (e.g., Alonge et al. 2007; Berg et al. 2013; Findell et al. 2011; Myoung and Nielsen-Gammon
2010), which demonstrates that wet soil is more favorable to trigger deep convection. However, this seems to contradict the findings from some other studies (Kang and Bryan 2011; Taylor et al. 2012), which suggest that convective precipitation falls preferentially over dry soils. The discrepancy is mainly due to the different perspectives, spatially or temporally, from which the soil-precipitation relationship is investigated (Guillod et al. 2015).

These results should be taken with some caution because they may be model specific, as well as model
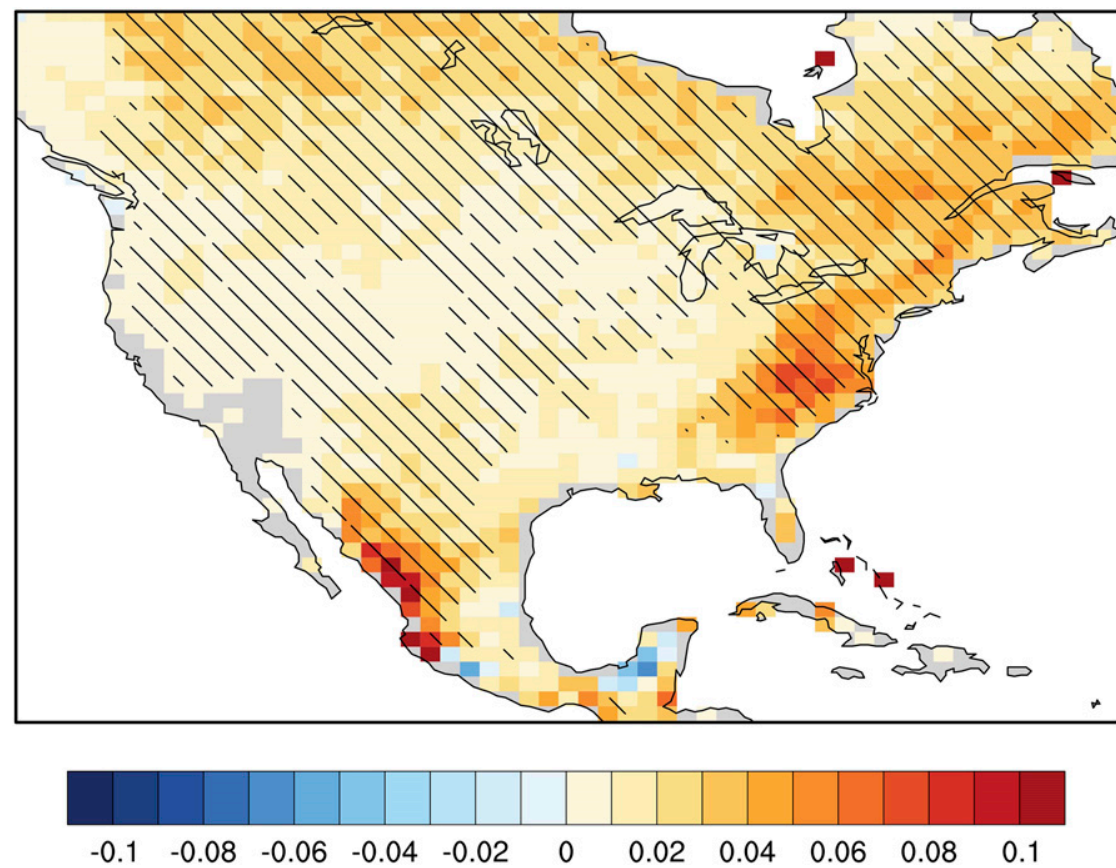

FIG. 13. Sensitivity of afternoon precipitation probability to morning EF based on CTP and $\mathrm{HI}_{\text {low }}$ criteria. Hatching indicates significance at the $95 \%$ confidence level. 
determined. Discrepancies have often been found among models in multimodel investigations of landatmosphere coupling (e.g., Koster et al. 2004, 2006; Guo et al. 2006; Koster et al. 2011). Mei and Wang (2012) have even found different coupling strengths among different CLM and CAM configurations. Furthermore, Earth system models may not represent the land-atmosphere process chain correctly. Dirmeyer et al. (2006) showed systematic biases among all GLACE participating models, and Wei et al. (2010) showed that erroneous precipitation spectra in climate models may bias coupling strength estimates. Also, land models and atmosphere models are usually developed separately and may not interact realistically when coupled. The compatibility issue may arise from the modular framework of most Earth system models, which limits testing and development in a coupled context based on coupled model process behaviors (cf. Dirmeyer et al. 2014b). Moreover, the criterion of convective triggering in this study is based on CAPE. However, the CAPE-based closure in model convective parameterizations may be overly pinned on the surface thermodynamic state (Sun and Pritchard 2016) and tends to produce earlier convection initiation and rainfall maxima than observations (Dirmeyer et al. 2012; Suhas and Zhang 2014), which could affect the delineation of afternoon precipitation in our study. Because CAPE-based convective triggering has been shown to be less than ideal, alternatives are being pursued (e.g., Chao 2013, Grell and Freitas 2014; Bombardi et al. 2016). Therefore, keen attention should be paid to the convective parameterization and its impacts on land-atmosphere interactions in any future studies.

Finally, although land-cover change can also alter land-atmosphere coupling strength (e.g., Badger and Dirmeyer 2015), an obvious change is only found in LH-CAPE coupling strength between the 1850 and 2000 experiments (Fig. S12 in the supplementary material). Generally, coupling strength becomes weaker and statistically insignificant when grasslands or forests are replaced with crops over some parts of the Midwest and Canada. The cooling and wetting effects of land-cover change over this region may actually lead to less sensitivity of the atmosphere to the moisture fluxes from the land surface. On the contrary, coupling strength gets stronger and significant when reforestation occurs in the northeastern United States. However, comparing with the LH-CAPE coupling strength in the 2000 experiment (Fig. 8a), the magnitude of its change is relatively small in the majority of the Great Plains. Therefore, land-cover types may exert an effect on land-atmosphere coupling strength but not a major change in this model. Nevertheless, it is an interesting contrast to the overall enhancement of coupling strength represented by climate models in global warming scenarios (Dirmeyer et al. 2013, 2014a).

\section{Conclusions}

This study investigates the impacts of historical landcover change on summer precipitation over North America, with the focus on the sensitivity of afternoon atmospheric conditions to morning land surface changes. Land-cover changes during the colonial and postcolonial periods constrained to eastern North America (from 850 to 1850) and later when agriculture shifted westward (from 1850 to 2000) are examined individually. The deforestation in the eastern United States prior to 1850 leads to increased LH but decreased SH during the morning and a reduction in precipitation over the southern regions of the U.S. East Coast. The agricultural activities over the Great Plains in the last century and a half show a similar pattern of surface flux changes but result in a significant widespread increase in precipitation over the new agricultural area while changes over the reforested eastern United States are fairly weak.

By using two-legged coupling metrics between land and atmosphere, coupling strength is explored between soil moisture and surface fluxes (land segment) and between surface fluxes and atmosphere properties like stability and precipitation (atmospheric segment). Both land and atmosphere segments indicate a coupling "hot spot" over the Great Plains, exhibiting a strong positive soil moisture-precipitation relationship. Over the Great Plains, the frequency of afternoon precipitation is sensitive to morning soil moisture and ET, while the intensity of afternoon precipitation is largely insensitive to the morning land surface condition. Land-cover change impacts manifest through changes in rainfall frequency that are largely controlled by the response to surface flux changes by CAPE, which acts as the trigger of convective precipitation. CAPE responds differently to changes in the partitioning of net radiation between latent and sensible heat flux over the southeastern United States than it does over the Great Plains, which has tended to synchronize the precipitation changes between these regions rather than producing a dipole that mimics the surface flux changes.

A notable teleconnection is also found in this experiment. Deforestation over the eastern United States prior to 1850 leads to a clear remote impact over parts of the southwestern United States, with a significant decrease in afternoon precipitation. This appears to occur 
through an alteration of the general circulation over North America also driven by the effect of surface flux changes on the distribution of atmospheric heating in the deforested area.

While the process chain by which land-use changes affect precipitation in this model has been shown, it is not necessarily true that nature responds in the same manner. We feel this is principally, although not entirely, because the simple CAPE triggering criterion used in the convective parameterization may produce incorrect sensitivities to surface flux changes. More thorough, detailed validation of coupled landatmosphere feedbacks and the behaviors within the links in the process chain connecting land surface states to climate responses such as precipitation is required, not just for this model but all weather and climate models.

Acknowledgments. Supercomputing resources for CESM simulations were provided by the National Science Foundation supported Computational Information Systems Laboratory supercomputing facility at the National Center for Atmospheric Research. This study was supported by the National Science Foundation Grant AGS-1419445. We also are grateful to the anonymous reviewers whose insightful comments helped improve our manuscript.

\section{REFERENCES}

Aires, F., P. Gentine, K. L. Findell, B. R. Lintner, and C. Kerr, 2014: Neural network-based sensitivity analysis of summertime convection over the continental United States. J. Climate, 27, 1958-1979, doi:10.1175/JCLI-D-13-00161.1.

Alfieri, L., P. Claps, P. D’Odorico, F. Laio, and T. M. Over, 2008: An analysis of the soil moisture feedback on convective and stratiform precipitation. J. Hydrometeor., 9, 280-291, doi:10.1175/ 2007JHM863.1.

Alonge, C. J., K. I. Mohr, and W.-K. Tao, 2007: Numerical studies of wet versus dry soil regimes in the West African Sahel. J. Hydrometeor., 8, 102-116, doi:10.1175/JHM559.1.

Anthes, R. A., 1984: Enhancement of convective precipitation by mesoscale variations in vegetative covering in semiarid regions. J. Climate Appl. Meteor., 23, 541-554, doi:10.1175/ 1520-0450(1984)023<0541:EOCPBM > 2.0.CO; 2 .

Badger, A. M., and P. A. Dirmeyer, 2015: Climate response to Amazon forest replacement by heterogeneous crop cover. Hydrol. Earth Syst. Sci., 19, 4547-4557, doi:10.5194/hess-19-4547-2015.

— , and — 2016: Remote tropical and sub-tropical responses to Amazon deforestation. Climate Dyn., 46, 3057-3066, doi:10.1007/s00382-015-2752-5.

Beck, H. E., A. I. J. M. van Dijk, V. Levizzani, J. Schellekens, D. G. Miralles, B. Martens, and A. de Roo, 2017: MSWEP: 3-hourly $0.25^{\circ}$ global gridded precipitation (1979-2015) by merging gauge, satellite, and reanalysis data. Hydrol. Earth Syst. Sci., 21, 589-615, doi:10.5194/hess-21-589-2017.

Berg, A., K. Findell, B. R. Lintner, P. Gentine, and C. Kerr, 2013: Precipitation sensitivity to surface heat fluxes over North
America in reanalysis and model data. J. Hydrometeor., 14, 722-743, doi:10.1175/JHM-D-12-0111.1.

Betts, A. K., 2004: Understanding hydrometeorology using global models. Bull. Amer. Meteor. Soc., 85, 1673-1688, doi:10.1175/ BAMS-85-11-1673.

Bombardi, R. J., A. B. Tawfik, J. V. Manganello, L. Marx, C.-S. Shin, E. K. Schneider, P. A. Dirmeyer, and J. L. Kinter III, 2016: The heated condensation framework as a convective trigger in the NCEP Climate Forecast System version 2. J. Adv. Model. Earth Syst., 8, 1310-1329, doi:10.1002/2016MS000668.

Chao, W. C., 2013: Catastrophe-concept-based cumulus parameterization: Correction of systematic errors in the precipitation diurnal cycle over land in a GCM. J. Atmos. Sci., 70, 35993614, doi:10.1175/JAS-D-13-022.1.

Chen, L., and A. P. Dirmeyer, 2016: Adapting observationally based metrics of biogeophysical feedbacks from land cover/ land use change to climate modeling. Environ. Res. Lett., 11, 034002, doi:10.1088/1748-9326/11/3/034002.

Collow, T. W., A. Robock, and W. Wu, 2014: Influences of soil moisture and vegetation on convective precipitation forecasts over the United States Great Plains. J. Geophys. Res. Atmos. 119, 9338-9358, doi:10.1002/2014JD021454.

Dai, A., 2006: Precipitation characteristics in eighteen coupled climate models. J. Climate, 19, 4605-4630, doi:10.1175/JCLI3884.1.

Dirmeyer, P. A., 2006: The hydrologic feedback pathway for landclimate coupling. J. Hydrometeor., 7, 857-867, doi:10.1175/ JHM526.1.

_ 2011: The terrestrial segment of soil moisture-climate coupling. Geophys. Res. Lett., 38, L16702, doi:10.1029/2011GL048268.

_- M. J. Fennessy, and L. Marx, 2003: Low skill in dynamical prediction of boreal summer climate: Grounds for looking beyond sea surface temperature. J. Climate, 16, 995-1002, doi:10.1175/1520-0442(2003)016<0995:LSIDPO>2.0.CO;2.

_ R. D. Koster, and Z. Guo, 2006: Do global models properly represent the feedback between land and atmosphere? J. Hydrometeor., 7, 1177-1198, doi:10.1175/JHM532.1.

— in global climate models: Resolution versus parameterization. Climate Dyn., 39, 399-418, doi:10.1007/s00382-011-1127-9.

_ , Y. Jin, B. Singh, and X. Yan, 2013: Evolving land-atmosphere interactions over North America from CMIP5 simulations. J. Climate, 26, 7313-7327, doi:10.1175/JCLI-D-12-00454.1.

— Z Z. Wang, M. J. Mbuh, and H. E. Norton, 2014a: Intensified land surface control on boundary layer growth in a changing climate. Geophys. Res. Lett., 41, 1290-1294, doi:10.1002/ 2013 GL058826.

—_, and Coauthors, 2014b: Advancing hydrometeorologicalhydroclimatic-ecohydrological process understanding and predictions. Hydrologic-Atmospheric Community Workshop White Paper, 12 pp. [Available online at http://inside. mines.edu/ thogue/nsf-hydro-atmo-workshop/NSFHydroAtmos WorkshopWhitePaper120314FINAL.pdf.]

Feddema, J. J., K. W. Oleson, G. B. Bonan, L. O. Mearns, L. E. Buja, G. A. Meehl, and W. M. Washington, 2005: The importance of land-cover change in simulating future climates. Science, 310, 1674-1678, doi:10.1126/science.1118160.

Findell, K. L., and E. A. B. Eltahir, 2003: Atmospheric controls on soil moisture-boundary layer interactions. Part II: Feedbacks within the continental United States. J. Hydrometeor., 4, 570-583, doi:10.1175/1525-7541(2003)004<0570:ACOSML>2.0.CO;2.

_ E. Shevliakova, P. C. D. Milly, and R. J. Stouffer, 2007: Modeled impact of anthropogenic land cover change on climate. J. Climate, 20, 3621-3634, doi:10.1175/JCLI4185.1. 
— P. Gentine, B. R. Lintner, and C. Kerr, 2011: Probability of afternoon precipitation in eastern United States and Mexico enhanced by high evaporation. Nat. Geosci., 4, 434-439, doi:10.1038/ngeo1174.

Ford, T. W., A. D. Rapp, S. M. Quiring, and J. Blake, 2015a: Soil moisture-precipitation coupling: observations from the Oklahoma Mesonet and underlying physical mechanisms. Hydrol. Earth Syst. Sci., 19, 3617-3631, doi:10.5194/hess-19-3617-2015.

$\_, \ldots$, and $—, 2015$ b: Does afternoon precipitation occur preferentially over dry or wet soils in Oklahoma? J. Hydrometeor., 16, 874-888, doi:10.1175/JHM-D-14-0005.1.

Fu, C., 2003: Potential impacts of human-induced land cover change on East Asia monsoon. Global Planet. Change, 37, 219-229, doi:10.1016/S0921-8181(02)00207-2.

Grell, G. A., and S. R. Freitas, 2014: A scale and aerosol aware stochastic convective parameterization for weather and air quality modeling. Atmos. Chem. Phys., 14, 5233-5250, doi:10.5194/acp-14-5233-2014.

Guillod, B. P., and Coauthors, 2014: Land-surface controls on afternoon precipitation diagnosed from observational data: Uncertainties and confounding factors. Atmos. Chem. Phys., 14, 8343-8367, doi:10.5194/acp-14-8343-2014.

- , B. Orlowsky, D. G. Miralles, A. J. Teuling, and S. I. Seneviratne, 2015: Reconciling spatial and temporal soil moisture effects on afternoon rainfall. Nat. Commun., 6, 6443, doi:10.1038/ncomms7443.

Guo, Z., and Coauthors, 2006: GLACE: The Global LandAtmosphere Coupling Experiment. Part II: Analysis. J. Hydrometeor., 7, 611-625, doi:10.1175/JHM511.1.

Harding, K. J., and P. K. Snyder, 2012: Modeling the atmospheric response to irrigation in the Great Plains. Part I: General impacts on precipitation and the energy budget. J. Hydrometeor., 13, 1667-1686, doi:10.1175/JHM-D-11-098.1.

Hurrell, J. W., J. J. Hack, D. Shea, J. M. Caron, and J. Rosinski, 2008: A new sea surface temperature and sea ice boundary dataset for the Community Atmosphere Model. J. Climate, 21, 5145-5153, doi:10.1175/2008JCLI2292.1.

Hurtt, G. C., and Coauthors, 2006: The underpinnings of land-use history: Three centuries of global gridded land-use transitions, wood-harvest activity, and resulting secondary lands. Global Change Biol., 12, 1208-1229, doi:10.1111/ j.1365-2486.2006.01150.x.

_ - and Coauthors, 2011: Harmonization of land-use scenarios for the period 1500-2100: 600 years of global gridded annual landuse transitions, wood harvest, and resulting secondary lands. Climatic Change, 109, 117-161, doi:10.1007/s10584-011-0153-2.

Kang, S.-L., and G. H. Bryan, 2011: A large-eddy simulation study of moist convection initiation over heterogeneous surface fluxes. Mon. Wea. Rev., 139, 2901-2917, doi:10.1175/ MWR-D-10-05037.1.

Koster, R. D., and Coauthors, 2004: Regions of strong coupling between soil moisture and precipitation. Science, 305, 11381140, doi:10.1126/science.1100217.

—- and Coauthors, 2006: GLACE: The Global Land-Atmosphere Coupling Experiment. Part I: Overview. J. Hydrometeor., 7 590-610, doi:10.1175/JHM510.1.

_ Z. Z. Guo, R. Yang, P. A. Dirmeyer, K. Mitchell, and M. J. Puma, 2009: On the nature of soil moisture in land surface models J. Climate, 22, 4322-4335, doi:10.1175/2009JCLI2832.1.

_ and Coauthors, 2011: The second phase of the Global LandAtmosphere Coupling Experiment: Soil moisture contributions to subseasonal forecast skill. J. Hydrometeor., 12, 805-822, doi:10.1175/2011JHM1365.1.
Lawrence, P. J., and T. N. Chase, 2010: Investigating the climate impacts of global land cover change in the Community Climate System Model. Int. J. Climatol., 30, 2066-2087, doi:10.1002/joc.2061.

_, and Coauthors, 2012: Simulating the biogeochemical and biogeophysical impacts of transient land cover change and wood harvest in the Community Climate System Model (CCSM4) from 1850 to 2100. J. Climate, 25, 3071-3095, doi:10.1175/JCLI-D-11-00256.1.

Mahmood, R., and Coauthors, 2014: Land cover changes and their biogeophysical effects on climate. Int. J. Climatol., 34, 929953, doi:10.1002/joc. 3736 .

Mei, R., and G. Wang, 2012: Summer land-atmosphere coupling strength in the United States: Comparison among observations, reanalysis data, and numerical models. J. Hydrometeor., 13, 1010-1022, doi:10.1175/JHM-D-11-075.1.

Myoung, B., and J. W. Nielsen-Gammon, 2010: The convective instability pathway to warm season drought in Texas. Part I: The role of convective inhibition and its modulation by soil moisture. J. Climate, 23, 4461-4473, doi:10.1175/ 2010JCLI2946.1.

Neale, R. B., and Coauthors, 2010: Description of the NCAR Community Atmosphere Model (CAM4.0). NCAR Tech. Note NCAR/TN-485+STR, 212 pp. [Available at http:// www.cesm.ucar.edu/models/ccsm4.0/cam/docs/description/ cam4_desc.pdf.]

Oleson, K. W., and Coauthors, 2013: Technical description of version 4.5 of the Community Land Model (CLM). NCAR Tech. Note TN-503+STR, 434 pp. [Available at http://www. cesm.ucar.edu/models/cesm1.2/clm/CLM45_Tech_Note.pdf.]

Otto-Bliesner, B. L., and Coauthors, 2015: Climate variability and change since $850 \mathrm{CE}$ : An ensemble approach with the Community Earth System Model (CESM). Bull. Amer. Meteor. Soc., 97, 735-754, doi:10.1175/BAMS-D-14-00233.1.

Pal, J. S., and E. A. B. Eltahir, 2001: Pathways relating soil moisture conditions to future summer rainfall within a model of the landatmosphere system. J. Climate, 14, 1227-1242, doi:10.1175/ 1520-0442(2001)014<1227:PRSMCT > 2.0.CO;2

Pielke, R. A., and Coauthors, 2007: An overview of regional landuse and land-cover impacts on rainfall. Tellus, 59B, 587-601, doi:10.1111/j.1600-0889.2007.00251.x.

Pitman, A. J., and Coauthors, 2009: Uncertainties in climate responses to past land cover change: First results from the LUCID intercomparison study. Geophys. Res. Lett., 36, L14814, doi:10.1029/2009GL039076.

Pongratz, J., C. Reick, T. Raddatz, and M. Claussen, 2008: A reconstruction of global agricultural areas and land cover for the last millennium. Global Biogeochem. Cycles, 22, GB3018, doi:10.1029/2007GB003153.

Qian, Y., M. Huang, B. Yang, and L. K. Berg, 2013: A modeling study of irrigation effects on surface fluxes and land-air-cloud interactions in the Southern Great Plains. J. Hydrometeor., 14, 700-721, doi:10.1175/JHM-D-12-0134.1.

Roundy, J. K., C. R. Ferguson, and E. F. Wood, 2013: Temporal variability of land-atmosphere coupling and its implications for drought over the southeast United States. J. Hydrometeor., 14, 622-635, doi:10.1175/JHM-D-12-090.1.

Santanello, J. A., and Coauthors, 2011a: Local land-atmosphere coupling (LoCo) research: Status and results. GEWEX News, No. 21, International GEWEX Project Office, Silver Spring, MD, 7-9.

, C. D. Peters-Lidard, and S. V. Kumar, 2011b: Diagnosing the sensitivity of local land-atmosphere coupling via the soil moisture-boundary layer interaction. J. Hydrometeor., 12, 766-786, doi:10.1175/JHM-D-10-05014.1. 
Seneviratne, S. I., and R. Stöckli, 2008: The role of landatmosphere interactions for climate variability in Europe. Climate Variability and Extremes during the Past 100 Years, S. Brönnimann et al., Eds., Springer, 179-193.

— interactions in a changing climate: A review. Earth Sci. Rev., 99, 125-161, doi:10.1016/j.earscirev.2010.02.004.

Song, H.-J., C. R. Ferguson, and J. K. Roundy, 2016: Landatmosphere coupling at the Southern Great Plains Atmospheric Radiation Measurement (ARM) field site and its role in anomalous afternoon peak precipitation. J. Hydrometeor., 17, 541-556, doi:10.1175/JHM-D-15-0045.1.

Suhas, E., and G. J. Zhang, 2014: Evaluation of trigger functions for convective parameterization schemes using observations. J. Climate, 27, 7647-7666, doi:10.1175/JCLI-D-13-00718.1.

Sun, J., and M. S. Pritchard, 2016: Effects of explicit convection on global land-atmosphere coupling in the superparameterized CAM. J. Adv. Model. Earth Syst., 8, 1248-1269, doi:10.1002/ 2016MS000689.

Tawfik, A. B., P. A. Dirmeyer, and J. A. Santanello, 2015: The heated condensation framework. Part II: Climatological behavior of convective initiation and land-atmosphere coupling over the conterminous United States. J. Hydrometeor., 16, 1946-1961, doi:10.1175/JHM-D-14-0118.1.

Taylor, C. M., R. A. M. de Jeu, F. Guichard, P. P. Harris, and W. A. Dorigo, 2012: Afternoon rain more likely over drier soils. Nature, 489, 423-426, doi:10.1038/nature11377.

— C. E. Birch, D. J. Parker, N. Dixon, F. Guichard, G. Nikulin, and G. M. S. Lister, 2013: Modeling soil moisture-precipitation feedback in the Sahel: Importance of spatial scale versus convective precipitation. Geophys. Res. Lett., 40, 6213-6218, doi:10.1002/2013GL058511.

Trail, M., and Coauthors, 2013: Potential impact of land use change on future regional climate in the southeastern U.S.: Reforestation and crop land conversion. J. Geophys. Res. Atmos., 118, 11 577-11 588, doi:10.1002/2013JD020356.

Vertenstein, M., A. Bertini, T. Craig, J. Edwards, M. Levy, A. Mai, and J. Schollenberger, 2013: CESM user's guide (CESM1.2 release series user's guide). NCAR Tech. Note, 884 pp. [Available online at http://www.cesm.ucar.edu/models/cesm1.2/cesm/doc/ usersguide/ug.pdf.]

Wei, J., and P. A. Dirmeyer, 2012: Dissecting soil moistureprecipitation coupling. Geophys. Res. Lett., 39, L19711, doi:10.1029/2012GL052351.

,,-- and Z. Guo, 2010: How much do different land models matter for climate simulation? Part II: A temporal decomposition of land-atmosphere coupling strength. J. Climate, 23, 3135-3145, doi:10.1175/2010JCLI3178.1.

Xu, Z., R. Mahmood, Z.-L. Yang, C. Fu, and H. Su, 2015: Investigating diurnal and seasonal climatic response to land use and land cover change over monsoon Asia with the Community Earth System Model. J. Geophys. Res. Atmos., 120, 11371152, doi:10.1002/2014JD022479.

Zhang, G. J., and N. A. McFarlane, 1995: Sensitivity of climate simulations to the parameterization of cumulus convection in the Canadian Climate Centre general circulation model. Atmos.-Ocean, 33, 407-446, doi:10.1080/ 07055900.1995 .9649539$. 